\title{
Biosilica incorporated 3D porous scaffolds for bone tissue engineering applications
}

\author{
Sedef Tamburaci ${ }^{\mathrm{a}}$, Funda Tihminlioglu ${ }^{\mathrm{b}, *}$ \\ a Izmir Institute of Technology, Graduate Program of Biotechnology and Bioengineering, Gülbahçe Campus, Urla, 35430 İmir, Turkey \\ b Izmir Institute of Technology, Department of Chemical Engineering, Gülbahçe Campus, Urla, İzmir 35430, Turkey
}

\section{A R T I C L E I N F O}

\section{Keywords:}

Diatomite

Scaffold

Bone

Chitosan

Silica

\begin{abstract}
A B S T R A C T
As a natural and abundant silica mineral, diatomite particles $\left(\mathrm{SiO}_{2}-\mathrm{nH}_{2} \mathrm{O}\right)$ have been used in several areas such as filtration, photonics, sound and heat insulation, filler material and drug delivery due to its abundance, inexpensive cost, unique morphology and porous structure. But up to date, diatomite incorporated silica based scaffolds have not been used for bone tissue engineering applications. In the present study, the goal was to combine the useful biomaterial properties of both chitosan and diatomite as biocomposite organic/inorganic biomaterial for bone tissue engineering applications and optimize the silica content of the composites in order to obtain optimum morphological structure, high mechanical properties, enlarged surface area and enhanced cell proliferation. The effect of silica loading on the mechanical, morphological, chemical, and surface properties, wettability and biocompatibility of composite scaffolds were investigated. In addition, in vitro cytotoxicity and cellular activities including cell proliferation, ALP activity and biomineralization were investigated in order to determine biological activity of the composite scaffolds. Diatomite particles lead to enhancement in the water uptake capacity of scaffolds. Chitosan-silica composites exhibited $82-90 \%$ porosity. Wet chitosan-silica composite scaffolds exhibited higher compression moduli when compared to pure chitosan scaffold in the range of 67.3-90.1 kPa. Average pore size range of chitosan-diatomite composite scaffolds was obtained as $218-319 \mu \mathrm{m}$. In vitro results indicated that chitosan-diatomite composites did not show any cytotoxic effect on 3T3, MG-63 and Saos- 2 cell lines. Scaffolds were found to be favorable for osteoblast proliferation. Diatomite incorporation showed promising effects on enhancing ALP activity as well as mineral formation on scaffold surface. Thus, the prepared scaffolds in this study can be considered prospective material for bone tissue engineering applications.
\end{abstract}

\section{Introduction}

In recent studies, composites consisting biopolymers and silica particles show potential in biomedical applications. Silicate nanoparticles have been extensively used to improve the mechanical properties of synthetic and natural polymers. These polymer nanocomposites often show significant improvements in structure, modulus, strength and toughness that cannot be achieved by using the polymer alone. Thus, silicate nanoparticles are commonly used for biomedical applications as reinforcements [1]. Besides, there have been a number of studies that revealed the biological functions of silica supporting bone cell adhesion and bone tissue formation by increasing the bioactivity of composites. Silica has an important role in biomineralization of bone tissue. The importance of $\mathrm{Si}$ on bone formation and calcification has been demonstrated through in vitro and in vivo studies. High Si contents have been detected in early stages of bone matrix calcification, and aqueous $\mathrm{Si}$ induced precipitation of hydroxyapatite in bone tissue by enhancing the bone ingrowth as a calcifying agent and its incorporation in the HAp is considered to be a potential method for improving the bioactivity of HAp [2]. Many studies investigating implants containing bioactive silicate found that the implants induce bone formation, stimulate osteogenic proliferation and activate bone-related gene expression. In addition, studies showed that silica induced $\mathrm{CaO}$ accumulation on the surface and nucleation of the apatite layer which is an essential step in the formation and mineralization of hard tissues $[1,3,4]$.

Diatomaceous earth $\left(\mathrm{SiO}_{2}-\mathrm{nH}_{2} \mathrm{O}\right)$ (diatomite) is a natural occurring mineral compound from skeletal remains of diatoms which are microscobic $(\sim 1-500 \mu \mathrm{m})$, non-motile, unicellular eukaryotic photosynthetic microalgae encased within a unique cell wall composed of silica (hydrated silicon dioxide) [5-7]. These single celled microalgae with more than 100,000 different species develop biomineralized external cell walls with unique morphologies which are composed of amorphous silica skeletons and organic materials $[5,8,9]$. This mineralized

\footnotetext{
* Corresponding author.

E-mail address: fundatihminlioglu@iyte.edu.tr (F. Tihminlioglu).
} 
exoskeleton is termed as "frustule". Diatom frustules are primarily amorphous agglomerations of very small silica particles in the order of a few ten nanometers. This type of $\mathrm{SiO}_{2}$ can react with $\mathrm{Ca}(\mathrm{OH})_{2}$ and produce calcium silicate hydrates (CSH) [10]. Diatomite has unique physical characteristics, such as high permeability $(0.1-10 \mathrm{mD})$ and porosity (35-65\%), small particle size, large specific surface area, low thermal conductivity, density and high absorption capacity with wellarranged pores on the outer or inner surfaces and a numerous sieve pores being approximately $40 \mathrm{~nm}$ for exchanging nutrients and gases. The porous structure of diatom frustules also increases their surface area possibly reaching $200 \mathrm{~m}^{2} / \mathrm{g}$ [11]. It has intrinsic properties such as relatively high melting-point, chemical inertness and small grain size [5,8,12-17]. Diatomite surface is terminated by $\mathrm{OH}$ groups and oxygen bridges. These groups act as adsorption sites on the surface [18].

The potential engineering and medical applications of diatom frustules have recently proposed, including metal film membrane, pinpoint drug delivery and nanopowder silica [5]. These frustules or purified silica powders obtained from frustules can be used to reinforce composites. A few studies exist regarding the use of diatoms for biomedical applications. Lopez-Alvarez et al. investigated the influence of silicon substituted hydroxyapatite coatings on osteoblast-like SaOs-2 cell line. Diatomaceous earth and synthetic silica with commercial hydroxyapatite were used to produce the Si-HAp coatings. In vitro cell culture results indicated that $\mathrm{Si}-\mathrm{HAp}$ coating from diatomaceous earth significantly favored osteoblast proliferation and activity in comparison to the Si-HAp coating from synthetic silica [16]. Hertz et al. prepared porous $\mathrm{SiO}_{2}$ and $\mathrm{SiO}_{2} / \mathrm{TiO}_{2}$ monoliths from Flux calcined diatomaceous earth and found that samples containing only $\mathrm{SiO}_{2}$ were proved to be biocompatible for bone tissue engineering [19]. In a study, raw diatomite (RD) and calcined diatomite (CD) powders were purified by acid treatments, and diatom microparticles (MPs) and nanoparticles (NPs) were produced. In vitro cytotoxic effect of diatom-derived particles was investigated. Results indicated that diatom particles had no cytotoxic effect on 3T3 cells and purification route could impact the cytotoxicity, especially in the case of microparticles [20].

In the present study, the goal was to combine the useful biomaterial properties of both chitosan and silica as biocomposite organic/inorganic biomaterials for bone tissue engineering applications. A number of articles are available in the literature on the promising properties of chitosan-silica composites. However, there is no literature regarding bone tissue engineering studies on composite scaffolds composed of natural silica source diatomite. This study is proposed to design novel chitosan-diatomite composites as scaffolds for bone tissue engineering applications and optimize the diatomite content of the composites to obtain optimum morphological structure, high mechanical properties, enlarged surface area and enhanced cell proliferation.

\section{Material \& method}

Chitosan low molecular weight powder (50,000-190,000 Da), was purchased from Sigma-Aldrich and used for preparation of composite scaffolds and Diatomite (Celpure ${ }^{\circledast} \mathrm{P} 65, \mathrm{SiO}_{2}, 98 \%$, Sigma-Aldrich) was used as natural silica source for reinforcement. Acetic acid (analytical grade, Sigma-Aldrich) was used as solvent preparation. Sodium hydroxide (NaOH-Sigma-Aldrich) was used for neutralization. BCA protein kit (Pierce, Thermofisher Scientific) and BSA (Bovine Serum Albumin-Aldrich, Sigma) were used for protein adsorption. Lysozyme (Aldrich, Sigma; from chicken egg white), sodium azide and phosphate buffer solution $(10 \times)$ (Sigma-Aldrich) were used for biodegradation studies. Simulated body fluid (SBF) was prepared for biomineralization tests. PBS (Phosphate Buffered Saline $10 \times$ ) solution (Lonza) was used for swelling studies. WST-1 assay (BioVision Inc.), Resazurin Cell Viability Kit (Cell Signaling Technology Inc.) and fluorometric STEMTAG $^{\mathrm{TM}}$ Alkaline Phosphatase Activity Kit (Cell Biolabs Inc.) were used for in vitro cell culture studies. Silver nitrate (Sigma, Aldrich), sodium thiosulfate (Sigma, Aldrich) Alizarin Red S (Sigma, Aldrich) were used for von Kossa and Alizarin Red staining. Paraformaldehyde (PFA, Merck), DAPI and Alexa Four 555 (Molecular Probes ${ }^{\mathrm{TM}}$, Thermo Fisher Scientific) stains were used for fluorescence imaging.

\subsection{Preparation of chitosan/diatomite composite scaffolds}

Chitosan/diatomite composite scaffolds were prepared by freeze drying method. Before use, diatomite particles were dried at $80^{\circ} \mathrm{C}$ for $24 \mathrm{~h}$ in order to remove moisture and prevent agglomeration. Chitosansilica composite dispersions were prepared by using separately prepared chitosan solutions and silica dispersion in acetic acid $(1 \% \mathrm{v} / \mathrm{v})$. Then they were mixed and sonicated with Misonix Ultrasonic Liquid Processor for $30 \mathrm{~min}$ at $15^{\circ} \mathrm{C}$ and 35 Amplitude for homogenization. Solution was poured into 24 and 48 well-plates for moulding. Then prefreezed at $-20^{\circ} \mathrm{C}$ for $24 \mathrm{~h}$. After prefreezing, samples were lyophilizied at $-46{ }^{\circ} \mathrm{C}$ and $0.01 \mathrm{mbar}$ vacuum. Freeze dried scaffolds were then stored in dessicator for further use. $1 \mathrm{M} \mathrm{NaOH}$ aqueous solution was used in order to neutralize remaining acetic acid residues. Prepared chitosan-silica composites were immersed in and washed with distilled water to remove remaining $\mathrm{NaOH}$.

\subsection{Characterization of chitosan/diatomite composite scaffolds}

\subsubsection{Mechanical analysis}

Mechanical strength of chitosan/silica composite scaffolds were measured by compression test according to the ASTM-D 5024-95a standard with TA XT Plus Texture Analyzer (Stable Micro Systems). Two experiment groups were designed for dry and wet conditions. Dry samples and hydrated samples were tested with 5 specimens for each group. Scaffolds were hydrated in PBS $\left(\mathrm{pH}=7.4\right.$, at $37^{\circ} \mathrm{C}$ ) for $1 \mathrm{~h}$ prior to testing and were kept immersed in PBS throughout the test. Compressive stress-strain curves were plotted and compressive elastic modulus $\left(\mathrm{E}^{*}\right)$ and compressive strength $\left(\mathrm{r}^{*}\right)$ were determined for all scaffolds Mechanical compression data are described as an average of five test specimens with standard error. Tests were performed with a cross-head speed of $5 \mathrm{~mm} / \mathrm{min}$ at room temperature and compressed up to $75 \%$ of original height.

\subsubsection{Scanning electron microscopy analysis}

Chitosan/diatomite composite scaffolds were analysed by SEM in order to observe surface morphology, pore size and distribution of diatomite frustules in chitosan matrix. Before the analysis, samples were coated with thin gold layer under argon gas by using Emitech K550X. Then SEM analysis was performed with Quanta FEG 250 (at $7 \times 10^{-2} \mathrm{mbar}$ and $15 \mathrm{~mA}$ ). Image $\mathrm{J}$ software was used to evaluate average pore size by using SEM images.

\subsubsection{Porosity determination}

Porosity of composite scaffolds was determined by mercury intrusion porosimeter (Micromeritics, AutoPore IV). Mercury is used in this technique because it is a non-wetting liquid that does not intrude into pore spaces except under sufficient pressure. The pressure required to intrude mercury into the sample's pores is inversely proportional to the size of the pores. Pore diameter-pressure relationship was evaluated by Washburn equation:

$D=-4 \gamma \cos \theta / P$

where D: pore diameter; P: pressure [21-23].

Porosity and 3D architecture of composite scaffolds were also determined by microtomography imaging using Scanco- $\mu$ CT 50 (Scanco Medicals, Switzerland) with penetrative X-rays of $45 \mathrm{kVp}-88 \mathrm{uA}$. Scaffolds were scanned at a native resolution with air filter. 500 slices was used for each specimen with $3 \mu \mathrm{m}$ voxel size in order to investigate the 3D structure of scaffolds.

Open porosity of scaffolds was also determined by liquid displacement method. Scaffolds were immersed in a graduated cylinder with 
ethanol $\left(V_{1}\right)$. The cylinder is then incubated in vacuum oven to discharge air from pores and provide ethanol enter through the pores. Then, total volume (ethanol and scaffold) is recorded as $V_{2}$. The volume difference $\left(V_{2}-V_{1}\right)$ is calculated as the volume of the skeleton of the scaffold. Finally, the scaffold is removed and the residual ethanol volume is measured as $V_{3}$. The open porosity of the scaffold is evaluated with the Eq. (2).

$\varepsilon=\left(V_{1}-V_{3}\right) /\left(V_{2}-V_{3}\right)$

\subsubsection{Protein adsorption assay}

In this study, first, composite scaffolds were incubated with $0.1 \%$ Bovine serum albumin (BSA) solution in order to determine the protein quantity adsorbed on surface. Experiment was carried out in 24 well plates. The sample specimens were incubated at $37^{\circ} \mathrm{C}$ for $24 \mathrm{~h}$ and $48 \mathrm{~h}$. The amount of adsorbed proteins on scaffolds was determined by BCA (Pierce, Rockford, IL) protein assay kit, using bovine serum albumin (BSA) as standard. The microplate procedure was used for protein determination adsorbed on samples.

\subsubsection{Water absorption capacity}

Swelling test was performed in order to obtain water uptake capacity of scaffolds in implanted tissue. Dry samples were weighed before test (Wd), immersed in 1XPBS solution and incubated at $37^{\circ} \mathrm{C}$ for $1 \mathrm{~h}$, $24 \mathrm{~h}$ and $48 \mathrm{~h}$. Then, wet samples were removed from plate and weighed (Ww). Extra solution on the surface was removed with filter paper before weighing. Swelling \% was determined with the following equation:

Swelling $\%=\left(W_{w}-W_{d}\right) / W_{d} \times 100$

\subsubsection{Enzymatic degradation study}

The enzymatic degradation of chitosan-silica composite scaffolds was performed at $37^{\circ} \mathrm{C}$ with phosphate-buffered solution (PBS, pH 7.4) containing $1.5 \mu \mathrm{g} / \mathrm{ml}$ lysozyme in order to mimic human serum [43]. $0.01 \%$ sodium azide was used to prevent bacterial contamination. The degradation medium was refreshed every $48 \mathrm{~h}$ periods to ensure continuous enzyme activity. Weight loss $\%$ of samples were investigated for $7,14,21$ and 28 day incubation periods. The extent of enzymatic degradation was expressed as percentage of weight loss of the dried scaffolds after lysozyme treatment. Enzymatic biodegradation was indicated by weight loss \% calculated using Eq. (4) as shown below;

Weight Loss\% $=W_{0}-W_{1} / W_{0}$

\subsubsection{Mineralization study}

In this study, mineralization process on composite scaffolds was tested in modified SBF solution (m-SBF $1 \times$ ) in order to mimic the in vivo condition [24]. Mineralization test with SBF was carried out by maintaining $\mathrm{pH}$ and temperature of solution to match the required for formation of an apatite mineral. During mineralization test, free calcium and phosphate ion concentrations decrease as mineralization progresses. Therefore, SBF medium was periodically refreshed for $48 \mathrm{~h}$ periods to provide the circulation. SEM analysis was performed with backscatter mode to investigate mineralization on scaffold surface. Mineral formation is evaluated by characterizing the calcium phosphate mineral formed on the material surface with EDX analysis.

\subsection{In vitro cell culture studies}

3T3, MG 63, Saos-2 and hFOB cell lines were used. Cells were maintained in DMEM and EMEM supplemented with $2 \mathrm{mM}$ L-glutamine, $10 \%$ fetal bovine serum, $100 \mu \mathrm{g} / \mathrm{ml}$ streptomycin and $100 \mathrm{U} / \mathrm{ml}$ penicillin in an atmosphere of $5 \% \mathrm{CO}_{2}$ at $37^{\circ} \mathrm{C}$. Sub-cultivation of cell lines was performed for every $48 \mathrm{~h}$.

\subsubsection{Cytotoxicity determination}

In vitro cytotoxicity of composite scaffolds was evaluated by the WST 1 assay by indirect extraction method according to ISO-10993 standard. Optical density was determined at $440 \mathrm{~nm}$.

Cell viability \% was determined by normalizing absorbance data of samples with absorbance data of negative control. Cell viability was calculated by using the equation:

Cell viability $\%=\frac{\text { Average absorbance value of treated samples }}{\text { Average absorbance value of control }} \times 100$

\subsubsection{In vitro cell proliferation on composite scaffolds}

MG 63 (Human osteosarcoma), Saos-2 (Human osteosarcoma) and hFob (human osteoblast) cell lines were subcultivated for in vitro cell culture studies. MG 63 cell line was cultivated in MEM Eagle's medium, Saos-2 and hFOB cell lines were cultivated in DMEM medium. Chitosan/diatomite scaffolds were sterilized with $70 \%(\mathrm{v} / \mathrm{v})$ ethanol before cell seeding overnight at room temperature in the laminar flow cabinet. Then ethanol was removed and scaffolds were washed with PBS thrice. Finally scaffolds were conditioned with cell culture medium for $2 \mathrm{~h}$ at $37^{\circ} \mathrm{C}$. 50000 cell/well were seeded on scaffolds $(1 \times 1 \mathrm{~cm})$ with $20 \mu \mathrm{l}$ inoculation volume and incubated $4 \mathrm{~h}$ without medium to obtain cell attachment on scaffold surface. During proliferation study, scaffolds were incubated at $37{ }^{\circ} \mathrm{C} / 5 \% \mathrm{CO}_{2}$ with $500 \mu \mathrm{l}$ medium in 48 well plates and medium was changed twice a week. The fluorometric resazurin cell viability kit (Cell Signaling Technology Inc.) was used to detect cellular metabolic activity. The resorufin formed in the assay was quantified by measuring the relative fluorescence units (RFU) using a fluorosecence plate reader (Varioskan Flash) at $530-570 \mathrm{~nm}$ excitation and 590-620 $\mathrm{nm}$ emission.

\subsubsection{Cell attachment and spreading on scaffolds}

Cell attachment and spreading on composite scaffolds was performed with MG 63 cells and analysed by SEM analysis and fluorescence microscopy. MG-63 cells were incubated on scaffolds for 3 and 7 days. Cells were incubated for 7 and 10 days on scaffolds and fixed with $3.7 \%$ paraformaldehyde $(\mathrm{v} / \mathrm{v})$ in PBS solution for $20 \mathrm{~min}$ at room temperature before DAPI-Alexa fluor 555 staining. Then washed with $1 \times$ PBS solution and permeabilized with $0.1 \%$ Triton X-100 for $5 \mathrm{~min}$. Dapi stain was used for detecting nuclei, whereas Alexa fluor 555 was subjected to cell membrane. The stained cells were examined and visualized by fluorescent microscopy. Quantification of the fluorescence intensity of DAPI stained cells on scaffold surface was analysed with Image $J$ program. In addition, MG-63 cells incubated on scaffolds for 3 days were analysed with SEM. The fixed cells on the surfaces were dehydrated in ethanol graded series $(50 \%, 70 \%, 80 \%, 90 \%$ and $100 \%)$ before SEM analysis.

\subsubsection{Determination of alkaline phosphatase (ALP) activity and osteocalcin production}

Cells were cultured with osteogenic medium on composite scaffolds for ALP activity and osteocalcin determination. Intracellular ALP activity of cells were quantified by fluorometric StemTAG ${ }^{\mathrm{TM}}$ ALP activity kit at 7, 14, 21 and 28 day incubation periods. Cell culture medium was aspirated and scaffolds were washed with cold PBS solution. Cells were incubated with cell lysis buffer for $20 \mathrm{~min}$ at $4{ }^{\circ} \mathrm{C}$ and centrifuged at $12000 \mathrm{~g}$ for $20 \mathrm{~min}$. Supernatant was used as cell lysate. $50 \mu \mathrm{l}$ cell lysate and $50 \mu 11 \times$ substrate solution (pNNP) were incubated at $37^{\circ} \mathrm{C}$ for $30 \mathrm{~min}$. The absorbance of mixture was measured by fluorescence plate reader (Varioskan Flash) at $480 \mathrm{~nm}$ excitation and $520 \mathrm{~nm}$ emission. Osteocalcin (OCN) production of MG-63 and Saos-2 cells incubated on scaffolds was measured using Sandwich-ELISA assay (Human OC/BGP (Osteocalcin) ELISA Kit, Elabscience). The culture media of scaffold groups were extracted for 21 and 28 days of incubation. 


\subsubsection{Determination of in vitro mineralization with Alizarin Red and Von} Kossa staining

Von kossa and alizarin red staining protocols were used to detect phosphate and calcium mineral formation by cells incubated on composite scaffolds. The von Kossa reaction remains the routine method for demonstrating calcium deposits in tissue with two-step reaction based on tissue calcium substitution, bound to phosphates by silver ions and the subsequent visualization of silver cations reacting with calcium deposit components [25,26]. Alizarin red staining is commonly used to detect and quantify calcium, while von Kossa staining is used to visualize phosphate within the deposited mineral [27]. Cells on scaffolds were fixed with $3.7 \%$ paraformaldehyde for $20 \mathrm{~min}$ at room temperature. Scaffolds were incubated with $1 \%(\mathrm{w} / \mathrm{v})$ aqueous silver nitrate solution silver nitrate solution for $30 \mathrm{~min}$ under UV light in laminar flow cabinet. Then silver nitrate solution was aspirated, scaffolds were rinsed with distilled water and incubated with $5 \%(\mathrm{w} / \mathrm{v})$ sodium thiosulfate solution for $5 \mathrm{~min}$ at room temperature to remove unreacted silver. Scaffolds were stained with $2 \%(\mathrm{w} / \mathrm{v})$ aqueous alizarin red $\mathrm{S}$ solution ( $\mathrm{pH} 4.1$ ) by incubating at room temperature in the dark for $30 \mathrm{~min}$. After incubation, alizarin red S solution was aspirated, scaffolds were rinsed with distilled water several times. Stained scaffolds were observed under stereomicroscope (SOIF DA 0737). In addition, semi quantitative analysis of calcium deposition on scaffolds was determined by alizarin red extraction and spectrophotometric analysis at $405 \mathrm{~nm}$.

\subsection{Statistical analysis}

All experiments were repeated thrice and samples were evaluated in triplicate. The experimental data is expressed as the standard deviation of the mean (SEM). Statistical analysis of mechanic test and swelling data were carried out using One-way ANOVA with Tukey's multiple comparison test $(\mathrm{p}<0.05)$. Statistical analyses of in vitro studies were carried out using two way ANOVA with Tukey's multiple comparison test $(\mathrm{p}<0.05)$.

\section{Results and discussion}

\subsection{Characterization}

\subsubsection{Mechanical characterization with compression test}

Mechanical characterization of chitosan/diatomite composite scaffolds were determined by compression test according to the ASTM-D 5024-95a standard. Compression modulus and strength of composite scaffolds groups containing up to $40 \%$ diatomite were determined in both dry condition as well as in wet conditions in order to mimic the in vitro condition. Mechanical properties of dry and wet chitosan/diatomite composite scaffolds were presented in Table 1. In dry condition, chitosan-diatomite composite scaffolds exhibited lower modulus and compressive strength when compared to pure chitosan scaffolds (Fig. 1a). Compression test results indicated that, diatomite reinforcement showed no significant effect on compression modulus and compressive strength. At lower concentrations (1-3\%) and higher concentrations (20-40\%) diatomite frustules having various non-uniform morphologies caused agglomerations and heterogenic distribution on scaffold structure. However, increasing diatomite concentration from $1 \mathrm{wt} \%$ up to $10 \mathrm{wt} \%$ enhanced the modulus of composite scaffolds. Above $10 \mathrm{wt} \%$ diatomite, moduli of composite scaffolds decreased with increasing diatomite concentrations. This decrease may arise from larger and brittle pore wall surfaces coated with diatomite particles. Besides, mechanical properties of a biomaterial are strongly related with its porosity and pore morphology [28]. Although porosity is an important factor for bone ingrowth, and permeability, higher pore size and porosity impair the mechanical properties by conducing decrease in compressive strength level [29-31].

Wang and coworkers investigated the mechanical properties of silica-chitosan hybrid porous scaffolds and indicated that high porosity
Table 1

Mechanical properties of dry and wet chitosan/diatomite composite scaffolds. Data was reported as mean \pm SE of five samples.

\begin{tabular}{|c|c|c|}
\hline \multirow[t]{2}{*}{ Groups } & \multicolumn{2}{|l|}{ Compression } \\
\hline & $\begin{array}{l}\text { Compression modulus } \\
(\mathrm{kPa})\end{array}$ & $\begin{array}{l}\text { Compressive strength } \\
(\mathrm{kPa})\end{array}$ \\
\hline \multicolumn{3}{|l|}{ Dry samples } \\
\hline Chitosan & $36 \pm 0.55$ & $128.8 \pm 1.47$ \\
\hline Chitosan- $1 \%$ diatomite & $17.4 \pm 1.88$ & $109 \pm 3.02$ \\
\hline Chitosan-3\% diatomite & $26.3 \pm 1.37$ & $107 \pm 2.48$ \\
\hline Chitosan-5\% diatomite & $30.8 \pm 1.77$ & $103.2 \pm 1.22$ \\
\hline $\begin{array}{r}\text { Chitosan-10\% } \\
\text { diatomite }\end{array}$ & $28.2 \pm 1.19$ & $127.8 \pm 2.76$ \\
\hline $\begin{array}{r}\text { Chitosan-20\% } \\
\text { diatomite }\end{array}$ & $25.6 \pm 0.8$ & $121 \pm 3.55$ \\
\hline $\begin{array}{r}\text { Chitosan-40\% } \\
\text { diatomite }\end{array}$ & $20.6 \pm 1.37$ & $128 \pm 2.81$ \\
\hline \multicolumn{3}{|l|}{ Wet samples } \\
\hline Chitosan & $56.3 \pm 7.42$ & $72 \pm 4.03$ \\
\hline Chitosan-5\% diatomite & $67.3 \pm 1.41$ & $62 \pm 5.10$ \\
\hline $\begin{array}{r}\text { Chitosan-10\% } \\
\text { diatomite }\end{array}$ & $65 \pm 4.10$ & $59 \pm 0.94$ \\
\hline $\begin{array}{r}\text { Chitosan-20\% } \\
\text { diatomite }\end{array}$ & $90.1 \pm 10.25$ & $64.3 \pm 2.68$ \\
\hline $\begin{array}{r}\text { Chitosan-40\% } \\
\text { diatomite }\end{array}$ & $81.4 \pm 3.01$ & $61.7 \pm 2.23$ \\
\hline Chitosan-5\% diatomite & $67.3 \pm 1.41$ & $62 \pm 5.10$ \\
\hline
\end{tabular}

caused low compressive strengths in the freeze cast hybrid scaffolds in the range of $150-250 \mathrm{kPa}$ along the freezing direction [32]. In another study, Wang et al. studied effect of silica concentration on mechanical properties of chitosan/silica composite scaffolds. Increasing the inorganic 3-Glycidoxypropyl trimethoxysilane (GPTMS: 4060 GC1) quantities resulted in the elastic-brittle deformation behavior. Increasing the amount of inorganic from $40 \%$ to $60 \%$ increased the yield strength from $66 \mathrm{kPa}$ to $94 \mathrm{kPa}$ [33]. Similarly, in our study, in dry condition, increasing diatomite concentrations had a negative effect on mechanical properties of composite scaffolds due to having large pores and high porosity. Compression modulus and strength of chitosan-diatomite composite scaffolds changed in a range of 17.4-20.6 and 109-128 kPa respectively. The difference between chitosan control group and 1, 3, 10, 20 and $40 \mathrm{wt} \%$ diatomite incorporated chitosan groups was found to be statistically significant at $\mathrm{p}<0.0001$.

In second experiment group, scaffolds were conditioned in PBS ( $\mathrm{pH}$ 7.4) solution for $1 \mathrm{~h}$ at room temperature before compression test. Wet scaffolds exhibited a flexible structure during compression. Scaffolds regained their initial shape and size after compression. In contrary to dry condition results, wet chitosan-diatomite composite scaffold exhibited significantly higher compression moduli in the range of $67.3-90.1 \mathrm{kPa}$ when compared to pure chitosan scaffold (56.3 kPa) (Fig. 1b). Statistically, no significant difference was obtained between wet chitosan and chitosan-diatomite composite groups, except $20 \mathrm{wt} \%$ diatomite loaded composites.

\subsubsection{Morphology and structure of composite scaffolds}

Pore size is an important factor in the progression of osteogenesis due to the fact that it induces vascularization in bone tissue growth. Generally, cancellous bone has a porous structure in a range of $30-90 \%$. Macro pores of scaffold provide favorable vascularization and results in osteogenesis. In vitro studies showed that, lower porosity stimulated osteogenesis by enhancing cell proliferation and inducing cell aggregation. On the other hand, higher porosity and pore size result in better bone ingrowth in vivo. The minimum requirement for pore size was considered to be approximately $100 \mu \mathrm{m}$ regarding cell size, migration requirement and transport. Recently, in vitro and in vivo studies indicated that pore size and interconnection larger than $300 \mu \mathrm{m}$ are suitable for sufficient vascularization of graft [29,34]. Porosity of 

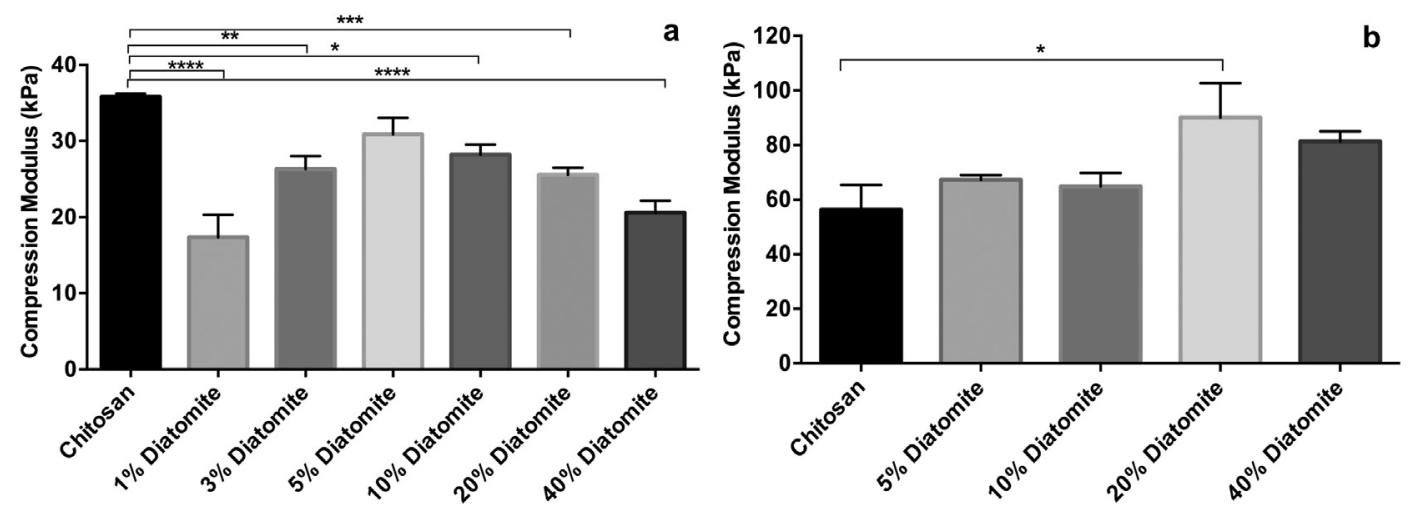

Fig. 1. Compression modulus of chitosan/diatomite composite scaffolds in dry and wet conditions.

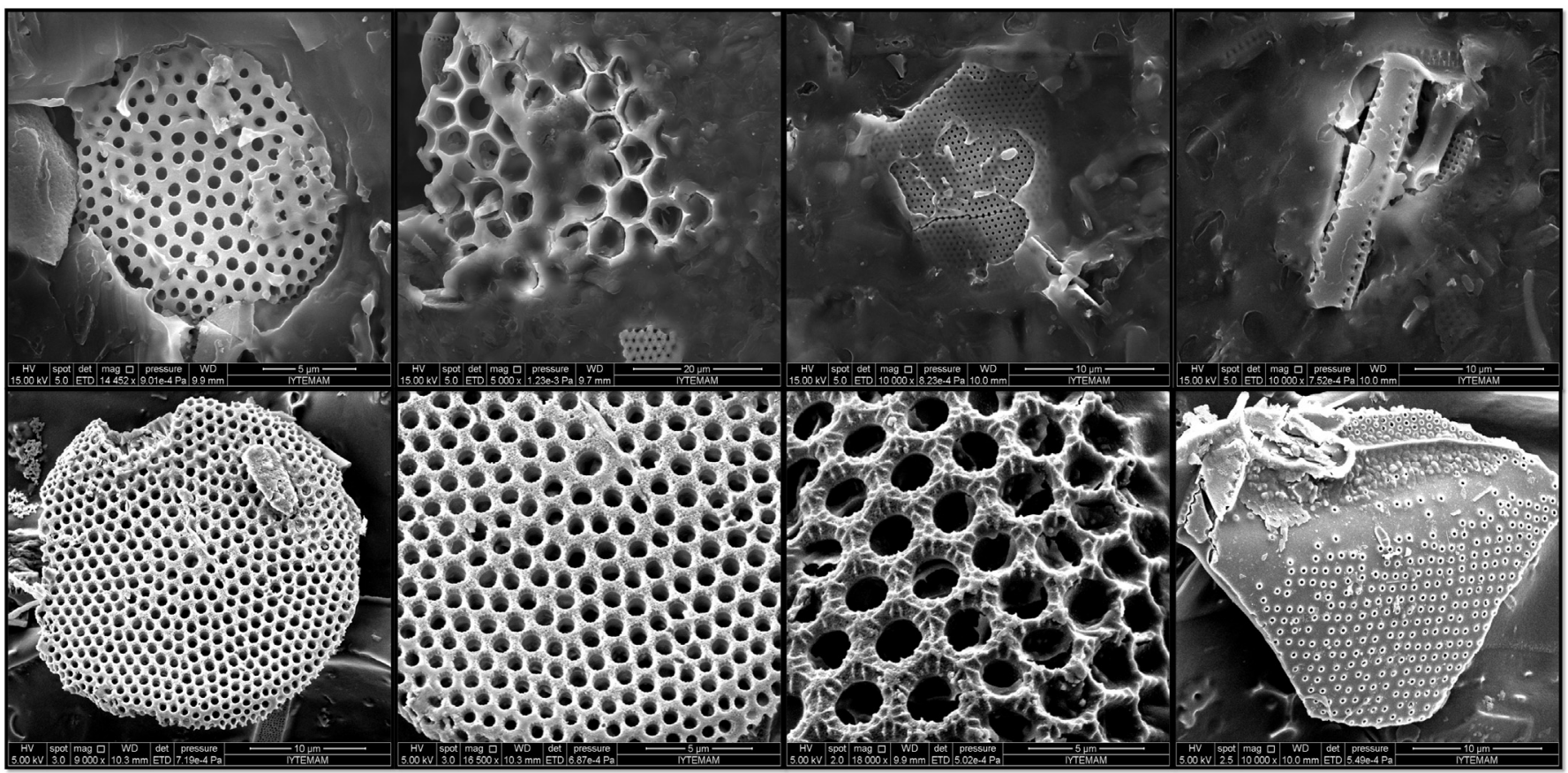

Fig. 2. Scanning electron micrographs of diatom frustules with different morphologies with 5,10 and $20 \mu \mathrm{m}$ scales.



Fig. 3. Scanning electron micrographs of chitosan scaffold with $100 \times(1 \mathrm{~mm}), 250 \times(500 \mu \mathrm{m})$ and $1000 \times(100 \mu \mathrm{m}) \mathrm{magnification}$.

scaffold depends on macro and micropores. Microporosity provides larger surface area inducing protein adsorption and ion exchange for apatite formation. On the other hand, macroporosity affects the osteogenesis [35]. In literature, the optimum pore size of a scaffold is defined as in the range of $75-250 \mu \mathrm{m}$ for bone tissue formation [36].
Chitosan/diatomite composite scaffolds were analysed in order to observe surface structure, pore size and distribution of diatomite particles in chitosan matrix. Surface structure, morphology and size distribution of lateral pores of composite scaffolds were determined by scanning electron microscopy (SEM). Lateral pore sizes were calculated 


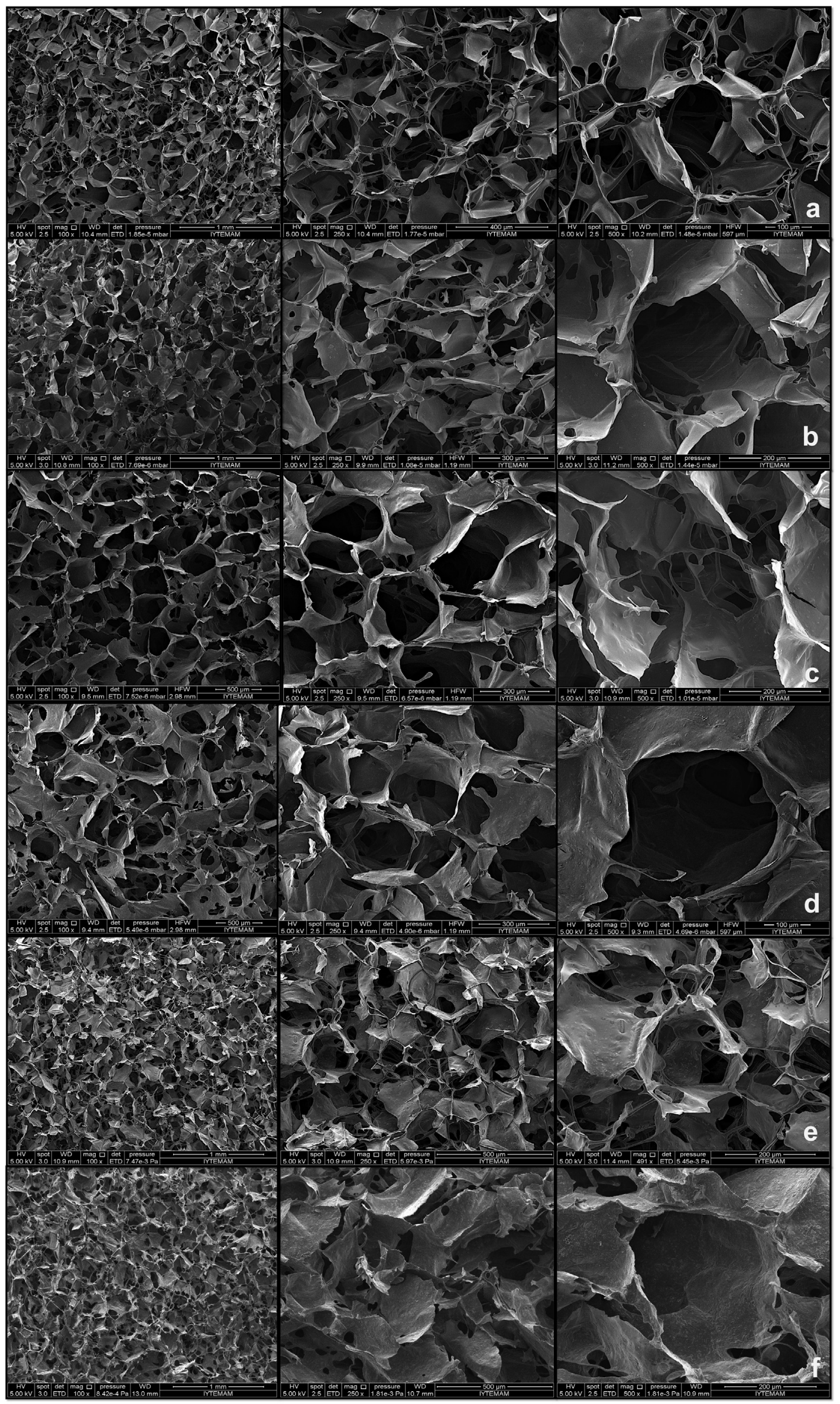

(caption on next page) 


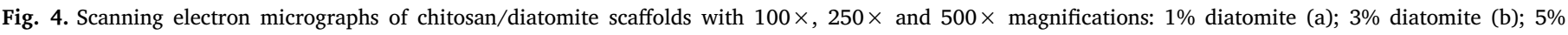
diatomite (c); $10 \%$ diatomite (d); $20 \%$ diatomite (e); $40 \%$ diatomite (f).

Table 2

Lateral pore size distribution of chitosan and chitosan/diatomite composite scaffolds.

\begin{tabular}{ll}
\hline Scaffold groups & Average pore size $(\mu \mathrm{m})$ \\
\hline Chitosan & $213 \pm 44$ \\
Chitosan-1\% diatomite & $297 \pm 102.4$ \\
Chitosan-3\% diatomite & $218 \pm 44.8$ \\
Chitosan-5\% diatomite & $260 \pm 65$ \\
Chitosan-10\% diatomite & $319 \pm 76$ \\
Chitosan-20\% diatomite & $287 \pm 49.4$ \\
Chitosan-40\% diatomite & $219 \pm 56.3$ \\
\hline
\end{tabular}

by using Image $\mathrm{J}$ software. The diverse morphology of porous diatom frustules with different microstructural properties on scaffold surface is presented in Fig. 2. Diatom frustules showed a pore size range of $0.3 \mu \mathrm{m}$ to $5 \mu \mathrm{m}$ in their structure.

SEM images of pure chitosan scaffolds showed that highly porous microstructure was obtained with freeze-drying method. Chitosan scaffolds exhibited uniform interconnected open pores with an average pore size of $213 \pm 44 \mu \mathrm{m}$ (Fig. 3). SEM images of chitosan-diatomite composite scaffolds also showed uniform highly porous structures. Average pore sizes were determined by using cross-section image of scaffolds. When compared with pure chitosan scaffold, surface area of pore walls increased and pore morphology of composite scaffolds changed with increasing diatomite content (Fig. 4). It was observed that pore size and morphology is affected by diatomite particles concentration and its dispersion level in polymer matrix. Average pore size range was obtained between 218 and $319 \mu \mathrm{m}$. Lateral pore size distributions of chitosan and chitosan/diatomite composite scaffolds are depicted in Table 2. An increase in diatomite content increased the pore size when compared to pure chitosan scaffolds. However, pore size increased up to $10 \mathrm{wt} \%$ diatomite contents. Above this concentration, pore size of the composite scaffold slightly decreased. In addition, above this concentration, surface morphology of the pores changed with increasing diatom content significantly. However, $20 \mathrm{wt} \%$ and $40 \mathrm{wt} \%$ diatomite contents showed uniform distributions of diatom frustules on surface which lead to favorable surface topography for cell adhesion and proliferation (Fig. 5).

\subsubsection{Porosity determination: mercury porosimeter, micro-CT analysis and liquid displacement method}

Adjusting the pore size is a crucial factor in scaffold design. Larger pores may be able to enhance the mass transport and neo-vascularization within the implants, whereas smaller pores are preferred to provide larger surface per volume ratio. Some specific pore sizes can enhance the cellular activity, but optimal size and geometry are highly dependent on specific cell types grown on injured sites. For bone in-growth, the optimal pore size is in the range of $75-250 \mu \mathrm{m}$ [36]. Mercury porosimetry is a characterization technique investigating only open pores between $500 \mu \mathrm{m}$ and $3.5 \mathrm{~nm}$ in a size range [22]. However, sample may collapse and compressed during the analysis causing error in measurements. Mercury porosimetry also has a limitation of measuring the largest entrance towards a pore. Therefore, this measurement may not represent the actual inner size of pore which may be larger than the entrance diameter [23]. In this study, scaffold porosity was determined by using three different methods; mercury porosimeter, liquid displacement and micro-CT analysis due the limitations exist in each measurement. Recently several studies used Micro CT analysis to determine the porosity and three-dimensional structure of scaffolds [37]. Scaffolds with intricate interior structures and different spatial locations can be analysed using micro CT [23]. Open micro/macro pore size range and porosity of the scaffolds were determined by mercury porosimeter under low pressure in order to prevent possible compression and disruption whereas, 3-D structure and porosity of scaffolds were analysed by micro-CT (Table 3). In addition, open porosity \% of scaffolds were verified with liquid displacement method.

Chitosan-diatomite composite scaffolds showed a morphology

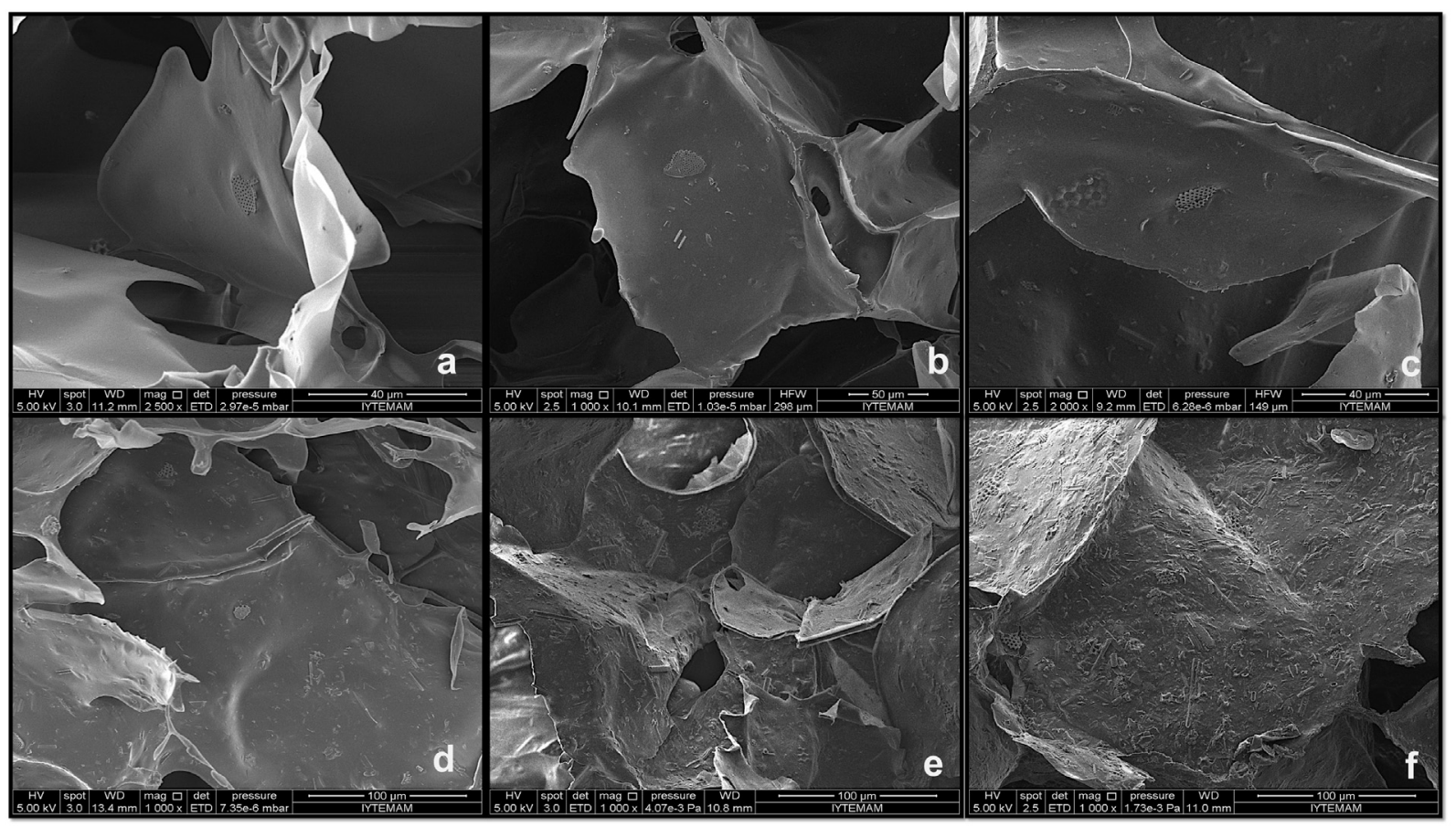

Fig. 5. Distribution of diatom frustules on scaffold surface: $1 \%$ diatomite (a); $3 \%$ diatomite (b); $5 \%$ diatomite (c); $10 \%$ diatomite (d); $20 \%$ diatomite (e); $40 \%$ diatomite (f) with $1000 \times$ and $2500 \times$ magnifications. 
Table 3

Porosity $\%$ of scaffolds determined by mercury porosimeter, micro-CT analysis and open porosity of scaffolds by liquid displacement method.

\begin{tabular}{|c|c|c|c|c|c|}
\hline \multirow[t]{2}{*}{ Groups } & \multicolumn{3}{|l|}{ Mercury porosimeter } & \multirow{2}{*}{$\begin{array}{l}\text { Micro-CT } \\
\text { Porosity (\%) }\end{array}$} & \multirow{2}{*}{$\begin{array}{l}\text { Liquid displacement } \\
\text { Open porosity (\%) }\end{array}$} \\
\hline & Micro-pore range $(\mu \mathrm{m})$ & Macro-pore range $(\mu \mathrm{m})$ & Porosity (\%) & & \\
\hline Chitosan & $10-70$ & $110-390$ & 89.25 & 87.5 & 77 \\
\hline Chitosan-5\% diatomite & $13-71$ & $105-267$ & 86.70 & 86.71 & 85 \\
\hline Chitosan-20\% diatomite & $10-98$ & $124-278$ & 90.80 & 90.76 & 81.3 \\
\hline Chitosan- $40 \%$ diatomite & $10-85$ & $108-225$ & 86.81 & - & 81.7 \\
\hline
\end{tabular}



Fig. 6. Micro CT images of chitosan (a), chitosan-5\% diatomite (b) and $20 \%$ diatomite (c) scaffolds showing morphology, 3D colored pore distribution and cross section respectively.

including micropores and macropores concerning the mercury porosimeter results. Results indicated that all scaffold groups showed high porosity $\%$ in a range of $\mathbf{8 7 - 9 1 \% . ~ A s ~ s e e n ~ i n ~ T a b l e ~ 3 , ~ m i c r o p o r e s ~ s i z e ~}$ ranges were found to be similar between groups obtained in the range of 10 to $98 \mu \mathrm{m}$. However, macropores size ranges differed within groups. Increasing diatomite concentrations from $20 \%$ to $40 \%$ decreased the size of macropores in the structure. Results indicate that chitosan-diatomite scaffolds can mimic the structure of cancellous bone and provide required porosity \% for bone cell growth. Fig. 6 depicted the three dimensional structure, morphology and interconnections of 5 and $20 \mathrm{wt} \%$ diatomite incorporated chitosan composite scaffolds. Micro CT images showed that all chitosan-diatomite composites exhibited highly porous structure. The results were found good agreement with those found by mercury porosimeter. Chitosan-5\% diatomite composite showed a homogeneous distribution of larger pores. However, increasing diatomite concentration altered the pore size distribution. Chitosan-20\% diatomite composite scaffold exhibited smaller pores at the center whereas, larger pores at the peripheral region. Liquid displacement method gave slightly lower porosity \% (81-85\%) compared to other two methods. This could be due to the lower vacuum pressure 

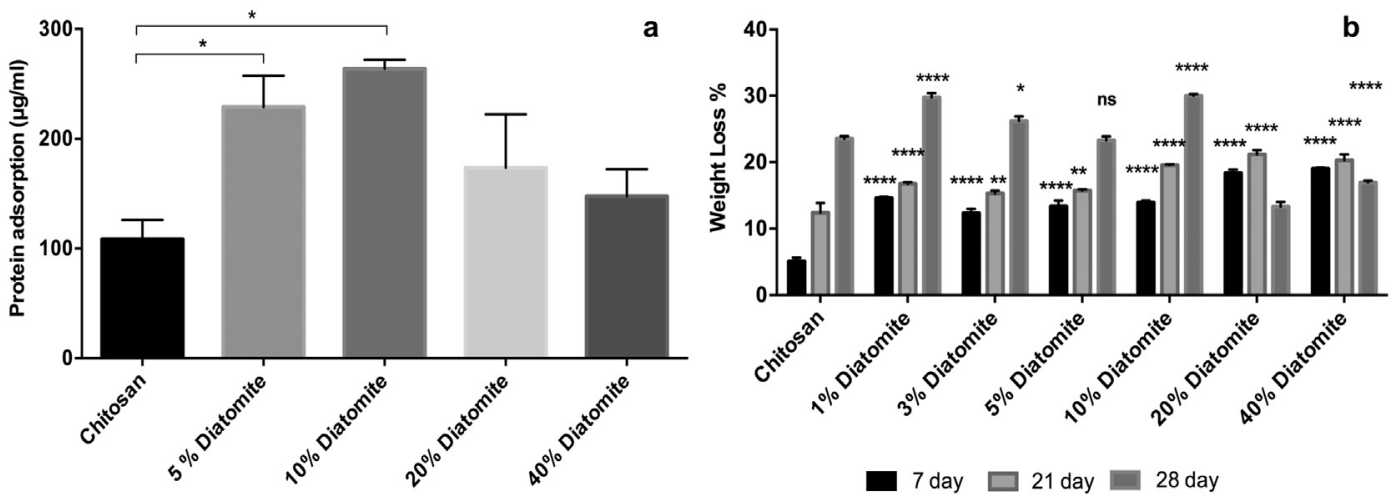

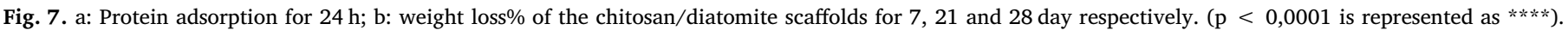

Table 4

Swelling ratio of chitosan/diatomite composite scaffolds. The data is presented as the mean \pm SE for three measurements.

\begin{tabular}{ll}
\hline Groups & Swelling ratio (24h) \\
\hline Chitosan & $26.8 \pm 0.34$ \\
Chitosan-1\% diatomite & $25.3 \pm 0.66$ \\
Chitosan-3\% diatomite & $27.5 \pm 0.24$ \\
Chitosan-5\% diatomite & $29.7 \pm 0.44$ \\
Chitosan-10\% diatomite & $37.1 \pm 0.41$ \\
Chitosan-20\% diatomite & $41.3 \pm 1.84$ \\
Chitosan-40\% diatomite & $44.22 \pm 2.62$ \\
\hline
\end{tabular}

applied on scaffolds to provide liquid enter through the pores and channels.

\subsubsection{Protein adsorption on scaffold surface}

The cell-substrate interaction by protein binding is the major factor during cell adhesion. This binding process determines the cell response on biomaterial surface [38]. After cell adhesion, cell monolayer is formed and cell-cell interactions come into prominence for cell migration and proliferation in tissue formation [39]. The understanding of protein-material interaction in biomaterial design provides a correlation between biomaterial and in vivo tissue responses at the defect site [40]. When biomaterial contacts with a fluid containing soluble proteins (blood, body fluid or cell culture media), protein adsorption on material surface takes place. Thus, cell does not contact the molecular structure of biomaterial when seeded. They contact and interact with the adsorbed protein layer. In this study, protein adsorption on both types of chitosan scaffolds was determined by using BCA colorimetric protein assay kit for $24 \mathrm{~h}$. Protein adsorption on neat chitosan scaffolds was obtained as $108 \mu \mathrm{g} / \mathrm{ml}$. For chitosan-diatomite composite scaffolds, protein adsorption increased up to $10 \%$ diatomite content and maximum adsorbed protein amount was determined as $264 \mu \mathrm{g} / \mathrm{ml}$ (Fig. 7a). $5 \%$ and $10 \%$ diatomite incorporation significantly enhanced protein adsorption compared to control group. Above this concentration, the protein adsorption decreased. This decrease may result from microstructure and pore surface alterations with increasing diatomite concentration. Our results are in good agreement with the study of Sowjanya et al. It was found that chitosan/alginate/nano-silica scaffolds showed a remarkable increase in the proteins adsorption at the initial period of $1 \mathrm{~h}$ incubation compared to chitosan/alginate scaffolds [41].

\subsubsection{Water uptake capacity determination}

Water uptake capacity of a biomaterial plays an important role when interacting with body fluids. Biomaterial must have hydrophilic character in order to provide a chemical interaction with the body fluids contents (i.e. proteins). Besides, blood or body fluid must be absorbed efficiently by the graft at the defect site. Swelling ratio of chitosan composite scaffolds were calculated using Eq. (2) and depicted in Table 4. Diatomite frustules are composed of silica particles and have hydrophilic character. Thus, incorporation of diatomite particles in chitosan matrix leads to enhancement in the water uptake capacity. The pore size and pore surface area differences obtained with increasing silica content effected swelling behavior of scaffolds positively. Water uptake capacity of scaffolds increased with increasing diatomite concentration in a range of $26.8-44.2$ (Table 4).

\subsubsection{Enzymatic degradation}

Ideally, the degradation rate of the scaffold should be matched with neo-tissue formation rate in order to procure a smooth transition of the load transfer from the scaffold to the newly formed tissue. However, studies showed that the degradation rate differs with the type and composition of the polymer, conditions of loading and ambient environment. The enzymatic degradation rate proceeds from the surface of the polymer. Therefore, surface area and porosity of the scaffold are major factors to control the degradation rate [36]. In literature, lysozyme enzyme has been used for degradation studies of chitosan. The degradation process of chitosan is generally dependent on the degree of acetylation. Highly acetylated chitosan shows faster degradation rate [42]. It is well known that, in human serum, N-acetylated chitosan is mainly depolymerized enzymatically by lysozyme which biodegrades the polysaccharide by hydrolyzing the glycosidic bonds present in the chemical structure [43]. Since chitosan is hydrophilic polymer, its degradation is due to bulk erosion. Diffusion of water into chitosan matrices is faster than degradation, therefore, chitosan matrices first begin to swell prior to degradation. Ren and co-workers reported that chitosan has two main degradation stages. In first stage chitosan interacts with water in the lysozyme solution, swells and this hydration process initiates the bond cleavage causing degradation and weight loss in second stage [44]. Fig. 7(b) shows the weight loss $\%$ of scaffolds in 7-21-28 day of incubation periods. In this study, similarly chitosandiatomite composite groups first began to absorb enzymatic solution and swell at the first stage of degradation (1-7 days) as Ren et al. reported for chitosan matrices. Then chitosan-diatomite groups showed a similar increase in weight loss \% trend compared to results of Ren and coworkers for 7-28 day of incubation. Higher weight loss\% were obtained in the first 3 weeks due to the high degree of acetylation of chitosan (75-85\%). Chitosan-diatomite (1-10 wt\%) composite scaffolds degraded in a range of $12 \%$ to $30 \%$ weight loss with 7-28 day of incubation Diatomite up to $10 \%$ significantly increased the weight loss $\%$ compared to chitosan scaffold. All diatomite groups showed similar degradation behavior between 7 and 28 day and increasing diatomite concentration increased the degradation rate. However, above $10 \%$ diatomite loading, a decrease on degradation rate was observed from 21 to 28 day of incubation. Chitosan-20\% diatomite and chitosan- $40 \%$ diatomite showed a significant decrease in weight loss $\%$ from 40 to 24.3 and 32.7 to $28 \%$ respectively between 21 and 28 day when compared to chitosan. This may stem from possible mineralization on 


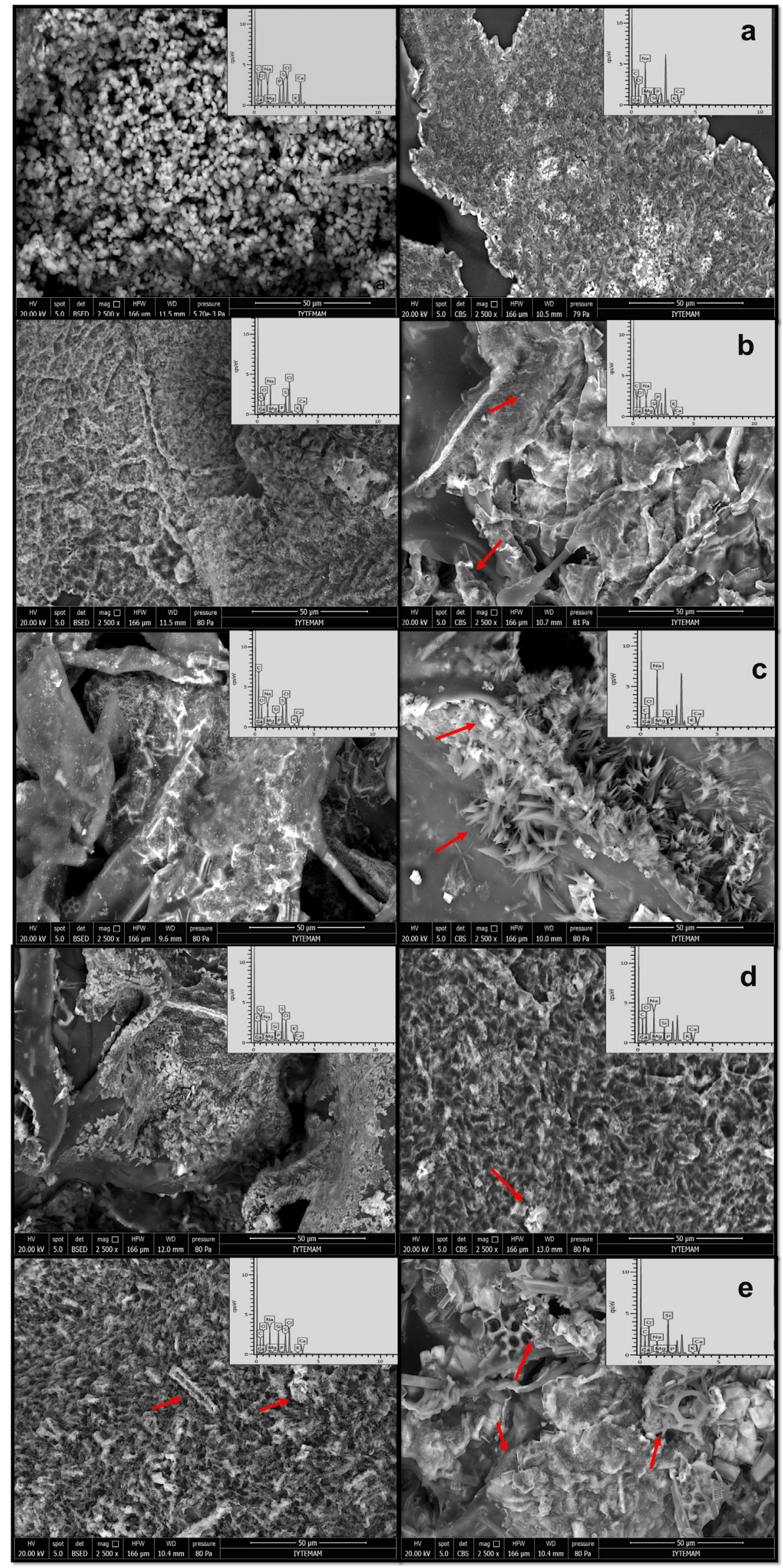





diatomite; $20 \%$ diatomite (c); $40 \%$ diatomite (d).

Table 5

$\mathrm{Ca} / \mathrm{P}$ ratio of Chitosan/diatomite composite scaffolds for 7 and 21 day incubations.

\begin{tabular}{lll}
\hline Groups & $\mathrm{Ca} / \mathrm{P}$ ratio (7 days) & $\mathrm{Ca} / \mathrm{P}$ ratio (21 days) \\
\hline Chitosan & 1.73 & 2.3 \\
Chitosan-5\% diatomite & 1.4 & 2 \\
Chitosan-10\% diatomite & 3.7 & 2 \\
Chitosan-20\% diatomite & 1.89 & 3 \\
Chitosan-40\% diatomite & 3.6 & 5 \\
\hline
\end{tabular}

composite surface with high diatomite concentration. Wan et al. indicated that the scaffold weight loss $\%$ changes with pore size and porosity that large pores and high porosity leads to higher weight loss $\%$. Besides the weight loss\% does not change linearly with the degradation time. Thus, scaffolds tend to degrade relatively fast in the first weeks. During this period, lysozyme can cleave chitosan molecules on the surface layer of scaffolds [45]. Similarly in this study, higher weight loss $\%$ was obtained for chitosan/diatomite composites in the first 3 weeks.

\subsubsection{Mineralization on scaffold surface}

SEM images indicated that, mineralization as apatite deposition which is the initiator of mineralization process was prominently determined on chitosan-diatomite composite scaffold surfaces. Globular shaped apatite aggregation grown on the pore walls was observed on chitosan scaffolds (Fig. 8a). On diatomite reinforced scaffolds, the dense apatite crystals are formed and organised as layers homogeneously covering the scaffold surface. Apatite crystals are observed in the form of clusters of needles on $5 \%$ diatomite incorporated scaffolds. EDX spectral analysis of the precipitates of composite scaffolds showed a Ca/ $\mathrm{P}$ ratio similar to stoichiometric $\mathrm{Ca} / \mathrm{P}$ (1.67) ratio of bone mineral. Composite surfaces showed a better mineral coating compared to neat chitosan (Fig. 8b, c, d, e). Increasing diatomite concentrations and soaking time increased mineral formation on scaffold surface. Ca ion accumulation was found to be significantly higher than phosphate ion accumulation on composite surfaces and increases with silica content (Table 5).

This fact may arise from calcium silicate formation on surface instead of calcium phosphate formation. The degradation of the silica network leads to the formation of $\mathrm{Si}-\mathrm{OH}$ groups at the bioactive composite-solution interface. The $\mathrm{Si}-\mathrm{OH}$ groups are involved in the apatite deposition through the hydration and dissolution of the silica network itself. Thus, it was concluded that silica particles initiated this mineral formation. Sowjanya et al. reported that nano-silica particles in CS/Alg/ $\mathrm{nSiO}_{2}$ scaffolds may initiate formation of a calcium phosphate layer due to electrostatic interactions of negatively charged Si-O units which are formed by $\mathrm{Si}-\mathrm{OH}$ dissociation, with the positively charged calcium ions in the SBF solution. As a result, calcium silicate layer was formed and exhibited a positive charge interacting with the negatively charged phosphate ions. By this way amorphous calcium phosphate formation was observed [41].

In literature it is indicated that silanol (Si-OH) groups, have favorable sites for the calcium phosphate nucleation. Moreover, in SBF solution the water molecules react with the $\mathrm{Si}-\mathrm{O}-\mathrm{Si}$ bond to form additional Si-OH groups. The silanol groups first chelate the calcium ions $\left(\mathrm{Ca}^{2+}\right)$. Then clusters of critical size are formed by adsorbing phosphates. These functional groups induce apatite nucleation, and the released $\mathrm{Ca}^{2+}$ and $\mathrm{Na}^{+}$ions accelerate apatite nucleation by inducing the ionic activity product (IAP) of apatite in the fluid. It has been suggested the calcium silicate continuously gains more positive charges until it begins to interact with the negatively charged phosphate ions in the SBF fluid to form amorphous calcium phosphate. This amorphous material would then be transformed into the crystalline apatite $\mathrm{Si}-\mathrm{OH}$ groups were found to be effective in apatite nucleation. Therefore, the mineralization process is induced by $\mathrm{Si}-\mathrm{OH}$ groups which are specific surface functional groups and serve as effective sites for heterogeneous nucleation of Ca-P [46,47].

\subsection{In vitro studies}

\subsubsection{Cytotoxicity determination}

WST 1 assay was performed on 3T3 cell line as specified in ISO standards for biocompatibility of materials. In addition, cytotoxicity determination was performed on MG-63 and Saos-2 cell lines which were used as bone cell models for in vitro cell culture studies. Cytotoxicity assay was not performed on Hfob cell line due to its lower proliferation rate and different incubation conditions $\left(33^{\circ} \mathrm{C}\right)$ compared to MG-63 and Saos-2 osteosarcoma cell lines. Cells seeded on 96-well plates were observed with microscope during incubation periods. In vitro cytotoxicity results were depicted in Fig. 9. Cell viability results indicated that chitosan/diatomite scaffolds didn't show any cytotoxic effect on 3T3, MG-63 and Saos-2 cell lines. In addition, chitosan-diatomite composite scaffolds showed proliferative effect on 3T3 cell line with high diatomite concentrations (5-40\%). For Saos-2 cell line, increasing diatomite loading in $20-40 \%$ range decreased cell viability for $24 \mathrm{~h}$ incubation. However, increasing diatomite loading between 1 and $10 \mathrm{wt} \%$, increased the cell viability for $24 \mathrm{~h}$ incubation. MG-63 cells interacted with $10-20 \%$ diatomite groups showed an increasing trend with incubation time and high cell viability was observed. Concerning the statistical differences and high cell viability results, diatomite concentrations between 5 and $20 \%$ had a positive effect on both MG-63


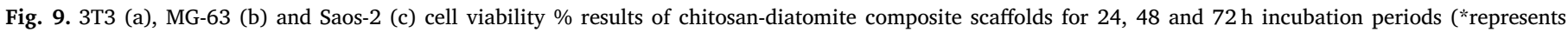
significant differences). 


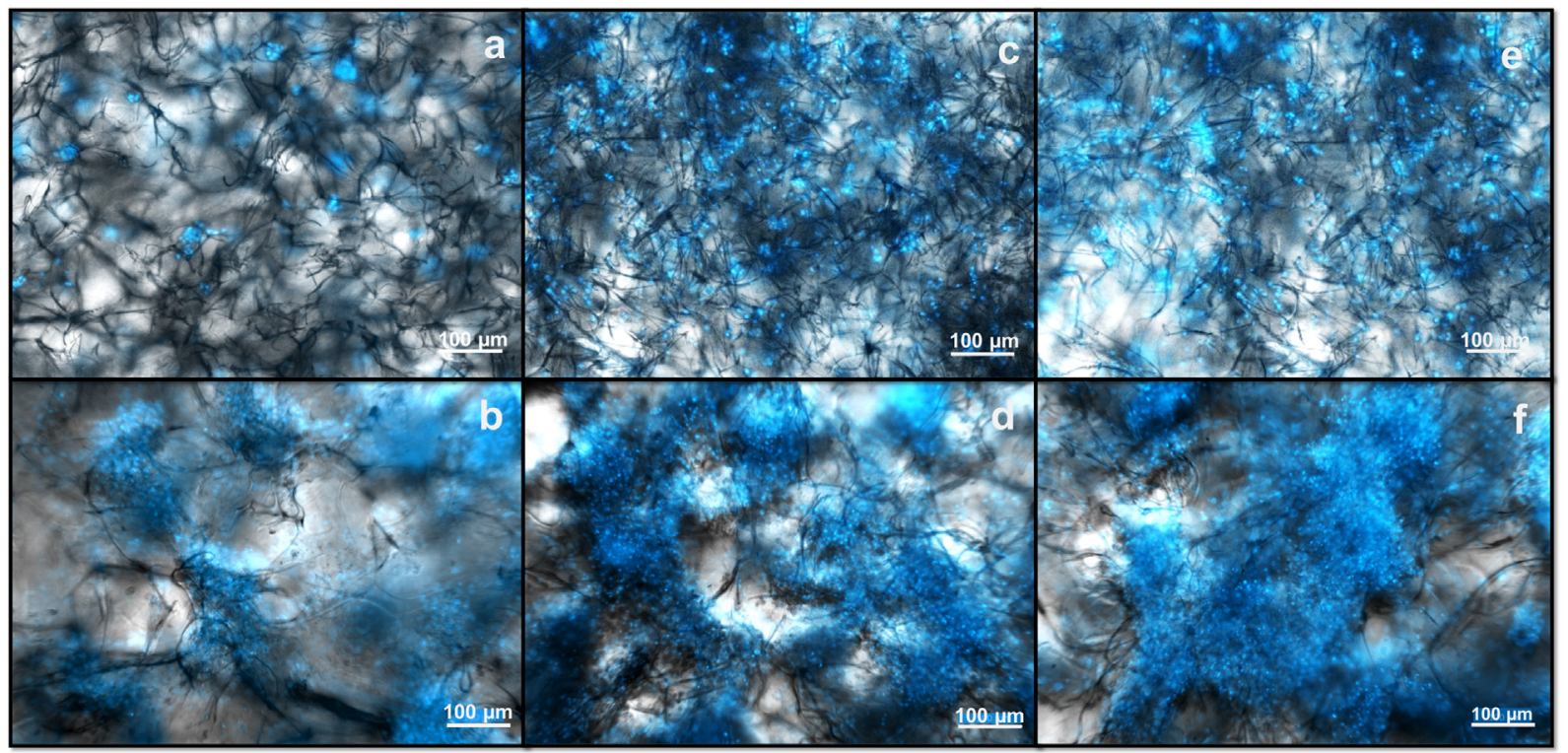

Fig. 10. Dapi-brightfield images of MG-63 cells on chitosan (a, b) chitosan-5\% diatomite (c, d) $20 \%$ diatomite (e, f) scaffolds for 7 days and 10 days respectively (10 $\times$ magnification- $100 \mu \mathrm{m}$ scale).

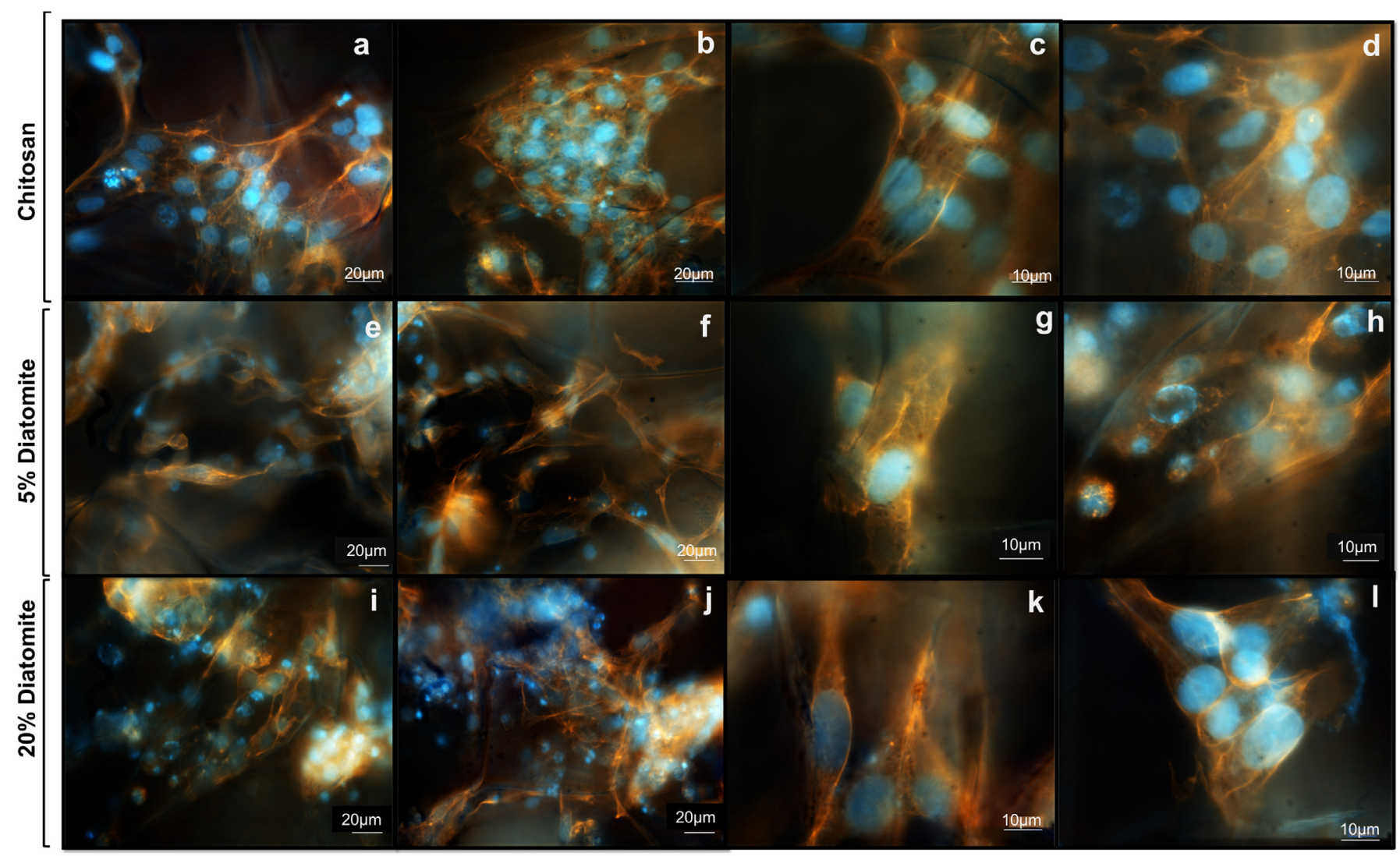

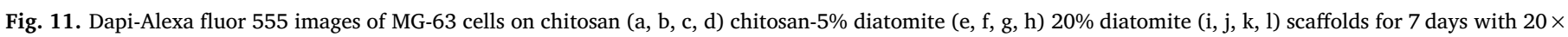
$(20 \mu \mathrm{m}$ scale $)$ and $40 \times(10 \mu \mathrm{m}$ scale $)$ magnifications.

and Saos-2 cell lines. Thus, diatomite concentration was used in the range of $5-40 \%$ for cell culture studies. In literature, in vitro cytocompatibility studies reported that the developed polymer- $\mathrm{nSiO}_{2}$ nanocomposites showed nontoxic behavior. Results indicated that the toxicity of $\mathrm{nSiO}_{2}$ could be highly reduced by blending it into composites, and nanocomposite scaffolds were found to be biocompatible with MG63, hMSCs, bMSCs cell lines [48].

\subsubsection{Cell attachment and spreading on scaffold}

Osteoblast/material interaction depends on the surface aspects of materials which can be defined regarding their topography, chemistry or surface energy. These surface characteristics determine the adsorption of biological molecules to the material surface and the orientation of adsorbed molecules [49]. Surface topography has been shown to affect cell/biomaterial interaction. Studies reported that enhanced cell 


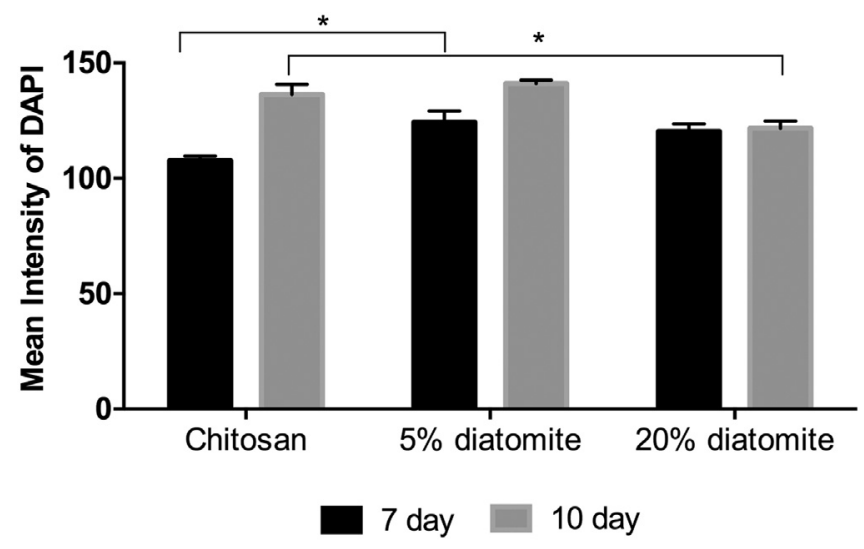

Fig. 12. DAPI intensity data of chitosan and chitosan-diatomite composite scaffolds at 7 th and 10th day.

attachment was obtained on textured polymer substrates. Cells preferentially adhere to the edges of pores $(10 \mu \mathrm{m}$ in diameter $)$ and pillars ( $50 \mu \mathrm{m}$ in depth) and also stretch between closely positioned features. Defining the topographic parameters has an influence on cell-biomaterial adhesion, by improving cell attachment and spreading [50]. Figs. 10-11 shows the florescence images of MG-63 cells attached on chitosan/diatomite scaffold surface with dapi-brightfield and dapialexa fluor 555 modes respectively. In this study, cell attachment and spreading study results showed that diatomite particles had a positive effect on cell attachment due to the change surface topography and surface roughness increase as investigated in our previous study on composite membranes [51]. Fluorescence images showed that cells were attached and spread well with cytoplasmic elongations on surfaces (Fig. 11d, h, l) and pore walls (Fig. 11c, g, k) of composite scaffolds. Fig. 12 shows the mean intensity data of DAPI staining of $100 \mu \mathrm{m}$ scale images. DAPI intensity significantly increased on 5\% diatomite loaded scaffolds for 7 day compared to chitosan. All groups showed an increasing trend with incubation period.

Improvement on cell attachment and spreading for chitosan-diatomite composite scaffolds were also confirmed by SEM images (Figs. 13-14). SEM images of 7th day showed that MG-63 cells attached and spread on the surface of pores and pore walls by forming mineralized layer on the surface of the scaffold (Fig. 14). Attached cells showed a typical osteoblastic phenotype having elongated polygonal and flat structures expressing filopodias in contact with the scaffold surface. MG-63 cells were also investigated with detailed SEM images at higher magnifications (Figs. 13-14).

\subsubsection{Cell proliferation on composite scaffolds}

In vitro cell proliferation studies were performed 7, 14, 21 and 28 day incubation periods with hFOB, MG 63 and Saos- 2 cell lines which are generally used as in vitro models for bone regeneration studies. Highly sensitive fluorometric rezasurin assay was used to determine cellular metabolic activity on scaffolds. Although osteosarcoma cells show osteoblastic properties, they differ in various terms, concerning proliferation kinetics and the osteoid production [52]. h FOB cell line mimics healthy human osteoblast cells with its morphology and osteogenic properties by comparison with osteosarcoma cell lines. Therefore, in this study, the effect of diatomite frustules was investigated on hFob proliferation. Studies indicated that MG-63 cell line may provide a good alternative for initial attachment to various materials. MG-63 cells were also found to be appropriate for studying the regulation and production of osteocalcin. Contrary to this, MG-63 cells

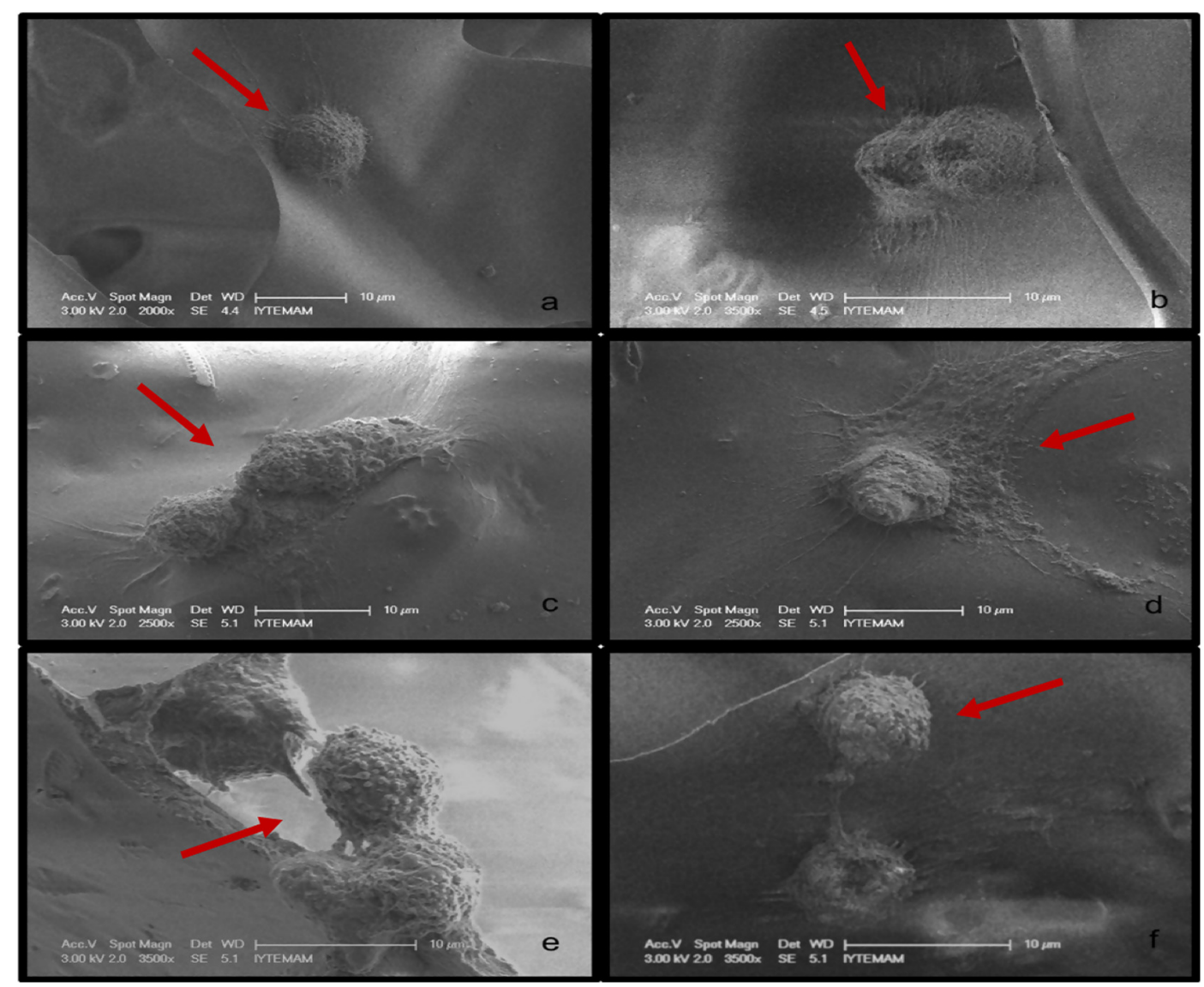

Fig. 13. Scanning electron micrographs showing MG-63 cells attached on chitosan (a, b) and chitosan-5\% diatomite (c, d) and $20 \%$ diatomite (e, f) scaffold surface for 3 days $(10 \mu \mathrm{m}$ scale). 

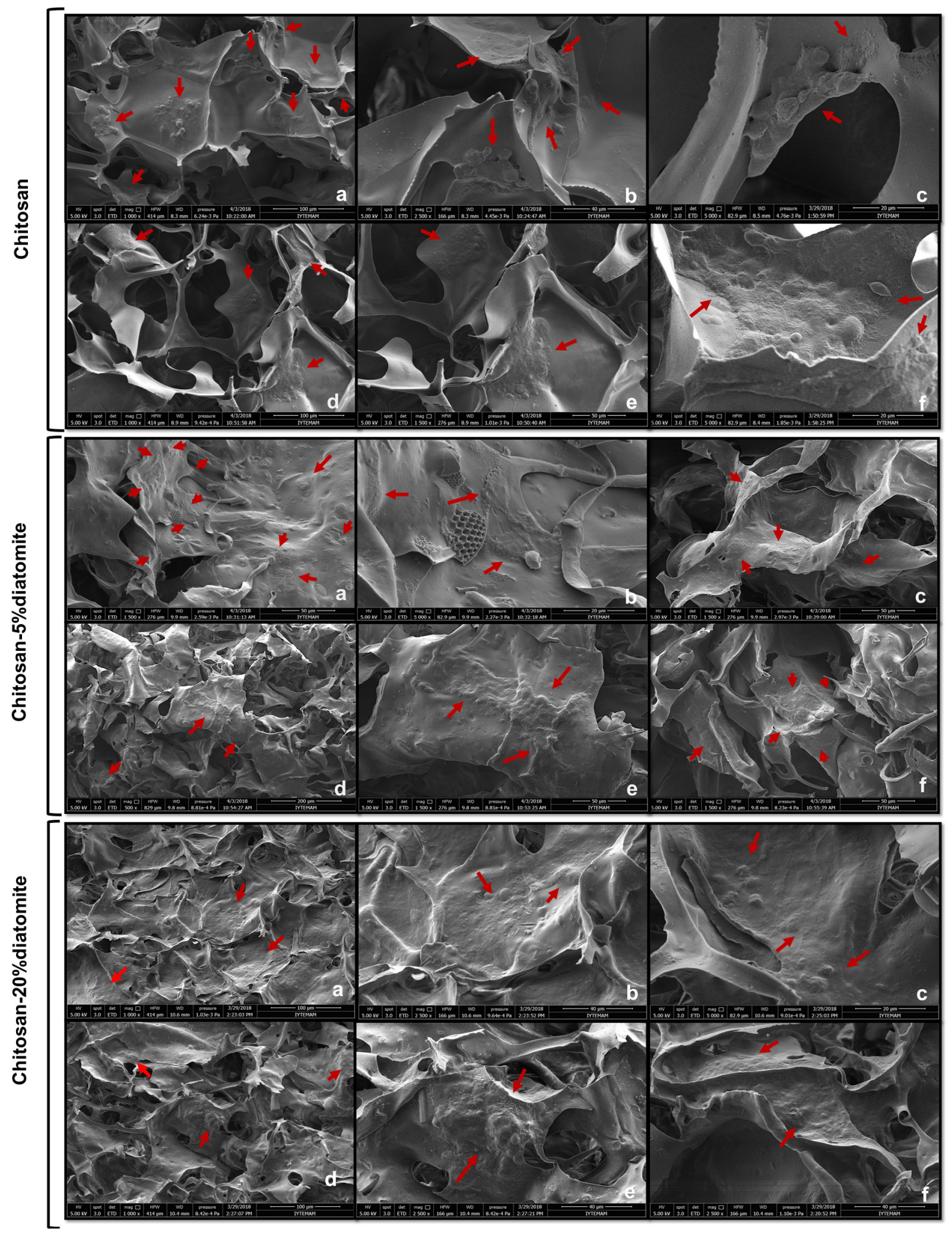

Fig. 14. Scanning electron micrographs of MG-63 cells attached on chitosan, chitosan-5\% diatomite and chitosan-20\% diatomite scaffold surfaces for 3 days (a, b, c) and 7 days (d, e, f) respectively: Chitosan $(100,50,20 \mu \mathrm{m})$, chitosan-5\% diatomite $(200,50,20 \mu \mathrm{m})$, chitosan-20\% diatomite $(100,40,20 \mu \mathrm{m})$.

were not very representative regarding proliferation and alkaline phosphatase activities [53]. Pautke and co-workers reported that osteosarcoma cell lines lack physiological features such as contact inhibition. Therefore, cell growth in culture is not restricted to monolayers. They have a typical characteristic of the malignant nature altering cellular functions like cell-to-cell communication [52]. In vitro proliferation of hFob, MG-63 and Saos- 2 cells on chitosan-diatomite scaffolds were depicted in Fig. 15(a, b, c) respectively. Results showed that h FOB cells proliferated on composite scaffolds during 28 day of incubation. Increasing diatomite concentrations showed a positive 

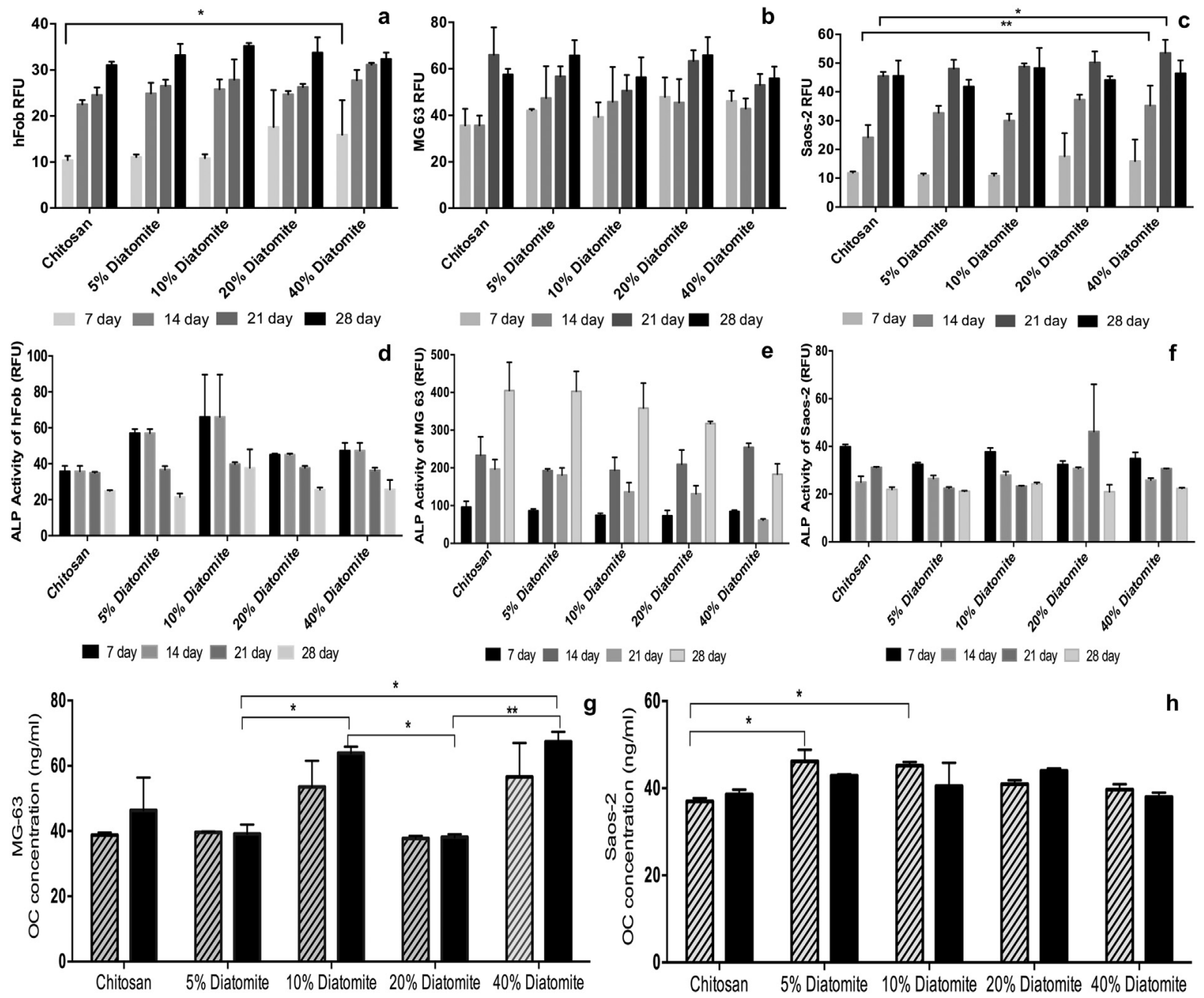

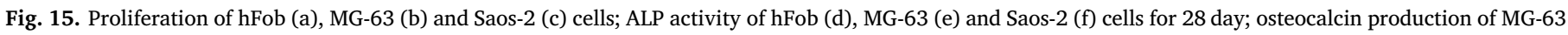
(g) and Saos-2 (h) cells for 21 and 28 days.

effect on hFOB proliferation. As expected, MG-63 osteosarcoma cells showed an increasing proliferation trend on composite scaffolds with incubation time. MG-63 cells proliferated rapidly on composite scaffolds compared to chitosan control group on 14th day of incubation. Saos-2 osteosarcoma cells also showed an upward trend, highly proliferating on scaffolds at the end of 21 day with increasing diatomite concentrations.

\subsubsection{Alkalen phosphatase activity (ALP) determination}

ALP studies were performed with MG-63, Saos-2 and hFob cell lines in osteogenic medium to determine the different osteogenic responses of these cell lines on composite scaffolds. Literature studies reported that, although MG-63 cells were identified as expressing a similar integrin subunit profile to hFOB cells, they had low ALP enzyme activity and did not mineralize [54,55]. Saos-2 cells with a mature osteoblast phenotype, possessed a high matrix mineralization capacity and showed higher ALP activity than other osteosarcoma cell lines, such as MG-63 [56]. Saldana and co-workers indicated that Saos-2 showed similar ALP activity compared to human primary osteoblast cells at the early time points, but 120 -fold higher ALP activity was observed after 14 day incubation [55]. Cytokine and growth factor expression of SaOs2 cells have been shown to be similar to primary normal human osteoblast cells [57]. SaOs-2 cells have been shown to express receptors specifically for parathyroid hormone (PTH) and calcitrol similar when compared to osteoblasts in vitro and in vivo [58]. As a consequence, SaOs-2 cells show responses resembling hFob cells more closely, regarding the expression of osteoblastic factors [59].

ALP activity of hFOB, MG-63 and Saos- 2 cells on chitosan-diatomite scaffolds were shown in Fig. 15(d, e, f) respectively. Results indicated that addition of diatomite frustules enhanced the ALP activity of hFob and Saos-2 cells at early stages. High ALP activity results were obtained on chitosan-diatomite scaffolds for 7 and 14 day incubation periods. Increasing diatomite concentrations showed a positive effect on Saos-2 cell at 14th day and increased the ALP activity. Above 10\% diatomite ALP activity of hFOB cells decreased. As expected, ALP activity decreased with incubation time. Consequently, Saos- 2 and hFOB cell lines showed similar responses in terms of ALP activity as indicated in literature studies. MG-63 cells exhibited ALP activity at the late term of incubation. However, much higher ALP concentrations were obtained with MG-63 cell line compared to Saos- 2 and hFOB cell lines. ALP activity of MG-63 cells increased on 5\% and 10\% chitosan-diatomite groups compared to control chitosan group. Above 10\% diatomite addition led to decrease in ALP activity composite groups. At higher diatomite concentrations (20\% and 40\%) ALP activity of MG-63 cells decreased due to the possible mineralization with high silica concentration on surface. In contradiction to Saos- 2 cell line, an increase in ALP activity was observed at the late stages of incubation for MG-63 cells. Statistically no significant difference was found between groups. In this study, incorporation of diatomite particles showed a positive effect on ALP activity of h FOB, Saos-2 and MG-63 cell lines. Since, osteocalcin is an important mineralization marker in osteoblast differentiation, osteocalcin secretion of cells incubated on chitosan-diatomite 



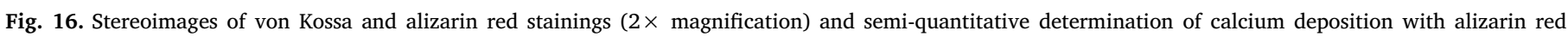


(b, d, f; h, j, l) respectively.

composite scaffolds were analysed with Human Osteocalcin ELISA assay. Fig. 15(g, h) shows the osteocalcin (OC) production of MG-63 and Saos- 2 cells on composite scaffolds for 21 and 28 days. Results indicated that OC secretion of MG-63 cells was found to be significantly higher on $10 \%$ and $40 \%$ diatomite incorporated scaffolds showing an increasing trend with incubation time. However, OC secretion of Saos-2 cells was significantly higher for $5 \%$ and $10 \%$ diatomite incorporated scaffold. In summary, incorporation of diatomite particles showed a positive effect on OC secretion of Saos-2 and MG-63 cell lines on the scaffolds.

\subsubsection{Biomineralization determination with von Kossa and Alizarin Red} staining

Von Kossa and Alizarin Red S stained scaffolds were observed under stereomicroscopy. In addition, cross section of scaffold is observed and mineral formation was detected at the inner parts of all scaffolds. Fig. 15 shows mineral formation of MG-63 and Saos- 2 cells on chitosan and chitosan-diatomite scaffolds with von Kossa and Alizarin Red staining for 28th day incubation. Slight amount of phosphate mineral formation was observed on MG-63 seeded chitosan scaffolds. Von Kossa stained composite scaffolds showed that $5 \%$ and $20 \%$ diatomite incorporation induced biomineralization of MG-63 cells on chitosan scaffolds. However, mineral formation was heterogenous changing concentrations at the center and peripheral regions due to the distribution of cells. This may stem from the morphology differences (porosity and pore size distribution) of composite scaffolds. On the other hand, Saos-2 cells prominently induced mineral formation on chitosan scaffolds. Von Kossa stained composite scaffolds showed that
Saos-2 cells were distributed homogenously and induced mineral formation on chitosan-diatomite scaffolds. Stereomicroscopy images depicted in Fig. 16 showed that MG-63 and Saos-2 cells induced mineralization on chitosan and chitosan-diatomite scaffolds (5\%-20\%) for 28 day incubation period. Scaffolds were cut into slices by surgical blade to observe the color change. However a distinctive difference of color change couldn't be observed between groups and incubation times as observed in von kossa and alizarin red staining. Consequently, mineral formation was detected on all composite groups. Therefore, Alizarin Red extraction method was used to determine the mineral formation difference between groups (Fig. 16). Semi quantitative results obtained from spectrophotometric measurements showed that diatomite incorporation enhanced the mineralization at early incubation period on surface compared to chitosan scaffold. Absorbance results indicated that $10 \%$ and $20 \%$ diatomite incorporated scaffolds enhanced the mineralization significantly at 21th day for both MG-63 and Saos-2 cells.

\section{Conclusion}

In this study, the novel biosilica loaded porous chitosan scaffolds were successfully prepared by lypholization technique. The effects of diatomite loading on the mechanical, morphological, chemical, and surface properties, wettability and biocompatibility of composites on different osteoblast cell lines were investigated. The obtained results showed that chitosan-biosilica composite scaffolds were highly porous morphology including micropores and macropores with a porosity range in the range of $87-91 \%$. Although diatomite addition decreased 
the compressive mechanical strength \& moduli of the dry composites, wet chitosan-diatomite composite scaffolds exhibited higher compression moduli when compared to pure chitosan scaffold in the range of $67.3-90.1 \mathrm{kPa}$. In addition, mineralization studies indicated that biosilica particles initiated the mineral formation on scaffold surface. Cell attachment and proliferation study results showed that chitosan-diatomite composites were found to be favorable for osteoblast proliferation. Diatomite frustules had a positive effect on cell attachment by altering surface topography. Diatomite incorporation showed high ALP activity and enhanced biomineralization on scaffold surface. Therefore, as a natural silica source, diatomite frustules can be used as a potential reinforcement in polymeric biomaterials for bone tissue applications. However, further studies must be conducted to determine the osteogenic effects of diatomite particles in vivo.

\section{Acknowledgments}

This study was supported by Republic of Turkey Ministry of Science Industry and Technology (0494.STZ.2013-2). The authors thank to Dr. Berivan Erik Cecen from Dokuz Eylul University Biomechanic Department for supplying MG-63 cell line, Prof. Dr. Ebru TOKSOY ONER from Marmara University Bioengineering Department for providing hFOB cell line and Assist. Prof. Dr. Meltem ALPER from Aksaray University for providing Saos-2 cell line. The authors are grateful to İzmir Institute of Technology (Iztech) Biotechnology and Bioengineering Research and Application Center (IZTECH BIOMER) for fluorescence microscopy analyses, Center for Materials Research (IZTECH CMR) for SEM and stereomicroscopy imaging and Ege University Central Application and Research Center for Micro Ct analyses.

\section{References}

[1] C.J. Wu, A.K. Gaharwar, P.J. Schexnailder, G. Schmidt, Development of biomedical polymer-silicate nanocomposites: a materials science perspective, Materials 3 (5) 2010) 2986-3005.

[2] A. El Yacoubi, A. Massit, M. Fathi, B.C. El Idrissi, K. Yamni, Characterization of silicon-substituted hydroxyapatite powders synthesized by a wet precipitation method, IOSR J. Appl. Chem. 7 (11) (2014) 24-29.

[3] K. Madhumathi, P.S. Kumar, K.C. Kavya, T. Furuike, H. Tamura, S.V. Nair, R. Jayakumar, Novel chitin/nanosilica composite scaffolds for bone tissue engineering applications, Int. J. Biol. Macromol. 45 (3) (2009) 289-292.

4] V. Puchol, J. El Haskouri, J. Latorre, C. Guillem, A. Beltrán, D. Beltrán, P. Amorós, Biomimetic chitosan-mediated synthesis in heterogeneous phase of bulk and mesoporous silica nanoparticles, Chem. Commun. (19) (2009) 2694-2696.

[5] K.M. Wee, T.N. Rogers, B.S. Altan, S.A. Hackney, C. Hamm, Engineering and medical applications of diatoms, J. Nanosci. Nanotechnol. 5 (1) (2005) 88-91.

[6] O. Şan, R. Gören, C. Özgür, Purification of diatomite powder by acid leaching fo use in fabrication of porous ceramics, Int. J. Miner. Process. 93 (1) (2009) 6-10.

[7] K.B. Narayanan, N. Sakthivel, Green synthesis of biogenic metal nanoparticles by terrestrial and aquatic phototrophic and heterotrophic eukaryotes and biocompatible agents, Adv. Colloid Interf. Sci. 169 (2) (2011) 59-79.

[8] J. Parkinson, R. Gordon, Beyond micromachining: the potential of diatoms, Trends Biotechnol. 17 (5) (1999) 190-196.

[9] C.S. Gaddis, K.H. Sandhage, Freestanding microscale 3D polymeric structures with biologically-derived shapes and nanoscale features, J. Mater. Res. 19 (09) (2004) 2541-2545.

[10] D. Kastis, G. Kakali, S. Tsivilis, M.G. Stamatakis, Properties and hydration of blended cements with calcareous diatomite, Cem. Concr. Res. 36 (10) (2006) 1821-1826.

[11] Y. Wang, J. Cai, Y, Jiang, X. Jiang, D, Zhang, Preparation of biosilica structures from frustules of diatoms and their applications: current state and perspectives, Appl. Microbiol. Biotechnol. 97 (2) (2013) 453-460.

[12] S. Scala, C. Bowler, Molecular insights into the novel aspects of diatom biology, Cell. Mol. Life Sci. 58 (11) (2001) 1666-1673.

[13] E.F. Stoermer, J.P. Smol, The Diatoms: Applications for the Environmental and Earth Sciences, Cambridge University Press, 2004.

[14] X. Cai, G. Zhu, W. Zhang, H. Zhao, C. Wang, S. Qiu, Y. Wei, Diatom-templated synthesis of ordered meso/macroporous hierarchical materials, Eur. J. Inorg. Chem. 2006 (18) (2006) 3641-3645.

[15] H. Hadjar, B. Hamdi, M. Jaber, J. Brendlé, Z. Kessaissia, H. Balard, J.B. Donnet, Elaboration and characterisation of new mesoporous materials from diatomite and charcoal, Microporous Mesoporous Mater. 107 (3) (2008) 219-226.

[16] M. Lopez-Alvarez, E.L. Solla, P. González, J. Serra, B. Leon, A.P. Marques, R.L. Reis, Silicon-hydroxyapatite bioactive coatings (Si-HA) from diatomaceous earth and silica. Study of adhesion and proliferation of osteoblast-like cells, J. Mater. Sci. Mater. Med. 20 (5) (2009) 1131-1136.

[17] H.E.G.M.M. Bakr, Diatomite: its characterization, modifications and applications, Asian J. Mater. Sci. 2 (3) (2010) 121-136.

[18] M.A. Khraisheh, Y.S. Al-degs, W.A. Mcminn, Remediation of wastewater containing heavy metals using raw and modified diatomite, Chem. Eng. J. 99 (2) (2004) $177-184$.

[19] A. Hertz, V. FitzGerald, E. Pignotti, J.C. Knowles, T. Sen, I.J. Bruce, Preparation and characterisation of porous silica and silica/titania monoliths for potential use in bone replacement, Microporous Mesoporous Mater. 156 (2012) 51-61.

[20] T.D.H. Le, W. Bonani, G. Speranza, V. Sglavo, R. Ceccato, D. Maniglio, C. Migliaresi, Processing and characterization of diatom nanoparticles and microparticles as potential source of silicon for bone tissue engineering, Mater. Sci. Eng. C 59 (2016) $471-479$.

[21] P.A. Webb, An Introduction to the Physical Characterization of Materials by Mercury Intrusion Porosimetry With Emphasis on Reduction and Presentation of Experimental Data, Micromeritics Instrument Corp, Norcross, Georgia, 2001.

[22] H. Giesche, Mercury porosimetry: a general (practical) overview, Part. Part. Syst. Charact. 23 (1) (2006) 9-19.

[23] S.T. Ho, D.W. Hutmacher, A comparison of micro CT with other techniques used in the characterization of scaffolds, Biomaterials 27 (8) (2006) 1362-1376.

[24] A. Oyane, H.M. Kim, T. Furuya, T. Kokubo, T. Miyazaki, T. Nakamura, Preparation and assessment of revised simulated body fluids, J. Biomed. Mater. Res. A 65 (2) (2003) 188-195.

[25] S.N. Meloan, H. Puchtler, Chemical mechanisms of staining methods: von Kossa's technique: what von Kossa really wrote and a modified reaction for selective demonstration of inorganic phosphates, J. Histotechnol. 8 (1) (1985) 11-13.

[26] J. Rungby, M. Kassem, E.F. Eriksen, G. Danscher, The von Kossa reaction for calcium deposits: silver lactate staining increases sensitivity and reduces background, Histochem. J. 25 (6) (1993) 446-451.

[27] C.D. Hoemann, H. El-Gabalawy, M.D. McKee, In vitro osteogenesis assays: influence of the primary cell source on alkalinephosphatase activity and mineralization, Pathol. Biol. 57 (4) (2009) 318-323.

[28] V. Guarino, F. Causa, L. Ambrosio, Bioactive scaffolds for bone and ligament tissue, Expert Rev. Med. Devices 4 (3) (2007) 405-418.

[29] D.W. Hutmacher, J.T. Schantz, C.X.F. Lam, K.C. Tan, T.C. Lim, State of the art and future directions of scaffold-based bone engineering from a biomaterials perspective, J. Tissue Eng. Regen. Med. 1 (4) (2007) 245-260.

[30] S.K.L. Levengood, M. Zhang, Chitosan-based scaffolds for bone tissue engineering, J. Mater. Chem. B 2 (21) (2014) 3161-3184.

[31] S. Wu, X. Liu, K.W. Yeung, C. Liu, X. Yang, Biomimetic porous scaffolds for bone tissue engineering, Mater. Sci. Eng. R. Rep. 80 (2014) 1-36.

[32] D. Wang, F. Romer, L. Connell, C. Walter, E. Saiz, S. Yue, J.R. Jones, Highly flexible silica/chitosan hybrid scaffolds with oriented pores for tissue regeneration, $\mathrm{J}$. Mater. Chem. B 3 (38) (2015) 7560-7576.

[33] D. Wang, W. Liu, Q. Feng, C. Dong, Q. Liu, L. Duan, Y. Liang, Effect of inorganic/ organic ratio and chemical coupling on the performance of porous silica/chitosan hybrid scaffolds, Mater. Sci. Eng. C 70 (2017) 969-975.

[34] S. Bose, M. Roy, A. Bandyopadhyay, Recent advances in bone tissue engineering scaffolds, Trends Biotechnol. 30 (10) (2012) 546-554.

[35] V. Karageorgiou, D. Kaplan, Porosity of 3D biomaterial scaffolds and osteogenesis, Biomaterials 26 (27) (2005) 5474-5491.

[36] H.Y. Cheung, K.T. Lau, T.P. Lu, D. Hui, A critical review on polymer-based bioengineered materials for scaffold development, Compos. Part B 38 (3) (2007) 291-300.

[37] F. Peyrin, Evaluation of bone scaffolds by micro-CT, Osteoporos. Int. 22 (6) (2011) 2043-2048.

[38] R.A. Latour, Biomaterials: protein-surface interactions, Encyclopedia of Biomaterials and Biomedical Engineering, 1 2005, pp. 270-278.

[39] K.L. Menzies, L. Jones, The impact of contact angle on the biocompatibility of biomaterials, Optom. Vis. Sci. 87 (6) (2010) 387-399.

[40] E. Servoli, D. Maniglio, M.R. Aguilar, A. Motta, B. Vazquez, J.S. Roman, C. Migliaresi, Comparative methods for the evaluation of protein adsorption, Macromol. Biosci. 9 (7) (2009) 661-670.

[41] J.A. Sowjanya, J. Singh, T. Mohita, S. Sarvanan, A. Moorthi, N. Srinivasan, N. Selvamurugan, Biocomposite scaffolds containing chitosan/alginate/nano-silica for bone tissue engineering, Colloids Surf. B: Biointerfaces 109 (2013) 294-300.

[42] T. Kean, M. Thanou, Biodegradation, biodistribution andtoxicity of chitosan, Adv. Drug Deliv. Rev. 62 (1) (2010) 3-11.

[43] T. Freier, H.S. Koh, K. Kazazian, M.S. Shoichet, Controlling cell adhesion and degradation of chitosan films by N-acetylation, Biomaterials 26 (29) (2005) 5872-5878.

[44] D. Ren, H. Yi, W. Wang, X. Ma, The enzymatic degradation and swelling properties of chitosan matrices with different degrees of N-acetylation, Carbohydr. Res. 340 (15) (2005) 2403-2410.

[45] Y. Wan, A. Yu, H. Wu, Z. Wang, D. Wen, Porous-conductive chitosan scaffolds for tissue engineering II. In vitro and in vivo degradation, J. Mater. Sci. Mater. Med. 16 (11) (2005) 1017-1028.

[46] N.M. Alves, I.B. Leonor, H.S. Azevedo, R.L. Reis, J.F. Mano, Designing biomaterials based on biomineralization of bone, J. Mater. Chem. 20 (15) (2010) 2911-2921.

[47] P. Jongwattanapisan, N. Charoenphandhu, N. Krishnamra, J. Thongbunchoo, I.M. Tang, R. Hoonsawat, W. Pon-On, In vitro study of the SBF and osteoblast-like cells on hydroxyapatite/chitosan-silica nanocomposite, Mater. Sci. Eng. C 31 (2) (2011) 290-299.

[48] S. Deepthi, J. Venkatesan, S.K. Kim, J.D. Bumgardner, R. Jayakumar, An overview of chitin or chitosan/nano ceramic composite scaffolds for bone tissue engineering, 
Int. J. Biol. Macromol. 93 (2016) 1338-1353.

[49] K. Anselme, Osteoblast adhesion on biomaterials, Biomaterials 21 (7) (2000) 667-681.

[50] S.C. Rizzi, D.J. Heath, A.G.A. Coombes, N. Bock, M. Textor, S. Downes, Biodegradable polymer/hydroxyapatite composites: surface analysis and initial attachment of human osteoblasts, J. Biomed. Mater. Res. 55 (4) (2001) 475-486.

[51] S. Tamburaci, F. Tihminlioglu, Diatomite reinforced chitosan composite membrane as potential scaffold for guided bone regeneration, Mater. Sci. Eng. C 80 (2017) 222-231.

[52] C. Pautke, M. Schieker, T. Tischer, A. Kolk, P. Neth, W. Mutschler, S. Milz, Characterization of osteosarcoma cell lines MG-63, Saos-2 and U-2 OS in comparison to human osteoblasts, Anticancer Res. 24 (6) (2004) 3743-3748.

[53] J. Clover, M. Gowen, Are MG-63 and HOS TE85 human osteosarcoma cell lines representative models of the osteoblastic phenotype? Bone 15 (6) (1994) 585-591.

[54] M.D. Pierschbacher, S. Dedhar, E. Ruoslahti, S. Argraves, S. Suzuki, An adhesion variant of the MG-63 osteosarcoma cell line displays an osteoblast-like phenotype,
CIBA Found. Symp. 136 (1988) 131-141

[55] L. Saldaña, F. Bensiamar, A. Boré, N. Vilaboa, In search of representative models of human bone-forming cells for cytocompatibility studies, Acta Biomater. 7 (12) (2011) 4210-4221.

[56] E. Murray, D. Provvedini, D. Curran, B. Catherwood, H. Sussman, S. Manolagas, Characterization of a human osteoblastic osteosarcoma cell line (SAOS-2) with high bone alkaline phosphatase activity, J. Bone Miner. Res. 2 (3) (1987) 231-238.

[57] G. Bilbe, E. Roberts, M. Birch, D.B. Evans, PCR phenotyping of cytokines, growth factors and their receptors and bone matrix proteins in human osteoblast-like cell lines, Bone 19 (5) (1996) 437-445.

[58] L.G. Rao, M.K. Sutherland, G.S. Reddy, M.L. Siu-Caldera, M.R. Uskokovic, T.M. Murray, Effects of 1a, 25-dihydroxy-16ene, 23yne-vitamin D 3 on osteoblastic function in human osteosarcoma SaOS-2 cells: differentiation-stage dependence and modulation by 17- $\beta$ estradiol, Bone 19 (6) (1996) 621-627.

[59] E.M. Czekanska, M.J. Stoddart, R.G. Richards, J.S. Hayes, In search of an osteoblast cell model for in vitro research, Eur. Cell. Mater. 24 (4) (2012) 1-17. 